\title{
Near-ground turbulence of the Bora wind in summertime
}

\author{
Petra Lepri $^{\mathrm{a}^{*}}, \check{Z ̌ e l j k o ~ V e c ̌ e n a j ~}^{\mathrm{b}}$, Hrvoje Kozmar $^{\mathrm{c}}$, Branko Grisogono $^{\mathrm{b}}$ \\ ${ }^{a}$ Meteorological and Hydrological Service, Grič 3, 10000 Zagreb, Croatia, e-mail: lepri@cirus.dhz.hr, \\ tel: +3859921166 43, corresponding author \\ ${ }^{b}$ Department of Geophysics, Faculty of Science, University of Zagreb, \\ Horvatovac 95, 10000 Zagreb, Croatia,e-mail:zvecenaj@gfz.hr, bgrisog@gfz.hr \\ ${ }^{c}$ Faculty of Mechanical Engineering and Naval Architecture, University of Zagreb, \\ Ivana Lučića 5, 10000 Zagreb, Croatia, e-mail:hrvoje.kozmar@fsb.hr
}

Abstract. Bora is a strong, temporally and spatially variable downslope wind that blows along the Eastern Adriatic Coast and many other dynamically similar places around the world. Bora mean velocity rarely exceeds $20 \mathrm{~m} / \mathrm{s}$, while its strong gusts create significant problems for engineering structures, traffic and agriculture. Previous meteorological and geophysical studies laid foundations on Bora large- and mesoscale motions, but further research is necessary to fully understand and resolve Bora turbulence in a form usable for engineers. In this study, unique high-frequency measurements, carried out simultaneously in three heights on a meteorological tower in the hinterland of the city of Split, Croatia, are analyzed for a single summertime Bora episode. Time histories and vertical profiles are studied for turbulence intensity, Reynolds shear stress and turbulence length scales in comparison with values recommended in major international wind engineering standards. Turbulence intensity and Reynolds shear stress proved to be not that sensitive to meandering of the mean wind velocity, as the observed values remain within the same range during the time record. This trend applies on mean wind velocities larger than $5 \mathrm{~m} / \mathrm{s}$, as for smaller velocities the spread of values increases considerably. Turbulence length scales are observed to increase with increasing mean wind velocity and vice versa. With increasing height from the ground, turbulence intensity and absolute Reynolds shear stress decrease, turbulence length scales increase, all in agreement with the atmospheric physics. However, while turbulence intensity, Reynolds shear stress and longitudinal turbulence length scales generally agree well with the values recommended in international standards for the respective terrain type, 
turbulence length scales related to lateral and vertical velocity fluctuations are much larger than the standard values.

Keywords: Gusty Bora wind; Turbulence; Turbulence intensity; Reynolds shear stress; Turbulence length scales; Field measurements.

\section{Introduction}

The gusty Bora wind characteristics are quite unknown to the wind engineering community, thus preventing accurate prediction of Bora wind loads on structures and vehicles. While most of the previous Bora research is performed for the Adriatic Coast, this type of wind commonly blows in other world regions as well, such as Japan, Russia, Kurdistan, Iceland, Austria, Rocky Mountains in the Northern America, etc. (e.g. Jurčec 1981, Neiman et al. 1988, Àgústsson and Ólafsson 2007, Jackson et al. 2013) thus making the Bora research globally applicable.

Along the Eastern Croatian Coast, Bora blows from the North East across the mountain ranges, from Trieste to Dubrovnik and further South (e.g. Yoshino 1976, Makjanić 1978, Bajić 1988, 1989, Tutiš 1988, Vučetić 1991, Belušić and Klaić 2004, 2006). Generally, Bora is a very strong, commonly dry and always gusty wind, which significantly influences optimal functioning of transportation networks, the agriculture, local wind energy yield as well as the fatigue of energy structures (e.g. Kozmar et al. 2012a, 2012b, 2014, 2015). While previous geophysical and meteorological studies laid ground on the macro-and meso-scale features of the Bora, (Jurčec 1981, Smith 1987, Grubišić 2004, Grisogono and Belušić 2009), further work is necessary to fully elucidate Bora turbulence in a form usable for wind engineers.

Bora mean wind speed, usually between $5 \mathrm{~m} / \mathrm{s}$ and $30 \mathrm{~m} / \mathrm{s}$, is not that significant to wind engineers as the Bora gusts that can sometimes reach velocities up to three or even five time the average wind speed (e.g. Petkovšek 1987, Belušić and Klaić 2004, 2006, Grisogono and Belušić 2009, Večenaj et al. 2010, Belušić et al. 2013). Spatially and temporally very variable, Bora is more common in winter when it can last from just a few hours up to several days (e.g. Jurčec 1981, Poje 1992, Enger and 
Grisogono 1998, Jeromel et al. 2009). Due to its extreme spatial variability, a precise and strict definition of the Bora wind is not available (e.g. Poje 1992, Horvath et al. 2009, Večenaj et al. 2012). Nevertheless, a certain data series is considered to belong to Bora event if the recorded time series of the horizontal wind component has the azimuth from the first quadrant and remains persistent for at least three hours with the mean wind speed larger than $5 \mathrm{~m} / \mathrm{s}$ and the standard deviation comparable to the mean value.

The occurrence of the long lasting Bora is commonly associated with a persistent cyclone over the Adriatic region or/and a high pressure centre over the Central or Eastern Europe, as the continental air is drawn by the cyclone from the lower troposphere across the mountains (e.g. Jurčec 1981, Heimann 2001, Belušić et al. 2013). Simultaneously, the air from the Pannonia Basin and the Central Europe is forced across the mountains towards the Adriatic by the anticyclone. A short lasting Bora can be triggered by the passage of the cold front across the Adriatic. Depending on the intensity and evolution of the cyclogenesis and its synchronization with the upper tropospheric flow, shallow or deep Bora may occur (e.g. Grisogono and Belušić 2009). Bora can be cyclonic, bringing clouds with high possibility for precipitation, anticyclonic, related to fair weather, and frontal (e.g. Jurčec and Visković 1994). The frequency of the Bora occurrence in the Eastern Adriatic decreases from North West to South East (e.g. Poje 1992), and its strength weakens seaward from the shore in a way that it is rarely stormy in the Western Adriatic (e.g. Enger and Grisogono 1998).

Development of advanced measuring techniques and numerical atmospheric models contributes to the progress of the Bora research, causing a change in basic understanding of the triggering system for a severe Bora. Originally, a katabatic-type perspective prevailed (e. g. Yoshino 1976, Jurčec 1981), while the issue with this approach was that simple katabatic flows are generally unable to continuously create mean wind velocities of around $20 \mathrm{~m} / \mathrm{s}$ and larger that is characteristic to Bora. At this moment, a hydraulic theory of strong to severe Bora with orographic wave breaking is commonly accepted in the mesoscale community, at least for the North Eastern Adriatic coast (Smith 1987, Enger and Grisogono 1998, Grubišić 2004, Grisogono and Belušić 2009). It was previously reported that the strong Bora flow can be treated, to a very good approximation, as a nonlinear hydraulic flow, which 

also means a lack of significant stratification effects (Klemp and Durran 1987, Smith 1987). A strong resonance between the flow and underlying terrain allows for the wave breaking phenomena to diminish stratification effects near the surface (e.g., Grisogono and Belušić 2009). Quasi-periodic behavior is a typical characteristic of downslope windstorm gusts (Petkovšek 1976, 1982, 1987, Rakovec 1987, Neiman et al. 1988). Belušić et al. (2004, 2006, 2007) showed that Bora pulsations usually emerge between 3 and 11 minutes. Due to the less complex orography with minor influence from the upwind mountains on the incoming flow, Bora has historically been more studied over the Northern Adriatic (e.g. Grisogono and Belušić 2009, Belušić et al. 2013).

Near surface Bora wind profile agrees well with the power-law and logarithmic-law approximations (Lepri at al. 2014). A decrease in the power-law exponent and aerodynamic surface roughness length, and an increase in friction velocity with increasing Bora wind velocity indicates a rural-like velocity profile for larger wind velocities and urban-like for smaller wind velocities. Due to strong mechanical mixing, Bora proved to be nearly neutrally thermally stratified. While for friction velocity and the power-law exponent the arithmetic mean and the median yield similar values independent on the averaging period, the more robust median proved to be more suitable when determining the aerodynamic surface roughness length.

In this study, detailed high-frequency Bora wind measurements carried out on a meteorological tower close to the city of Split, Croatia, at the Eastern Adriatic Coast, are analyzed to resolve some fundamental properties of the Bora turbulence. A particular focus is on the Bora turbulence intensity, Reynolds shear stress and turbulence length scales.

\section{Methodology and the data}

Turbulence intensity, as a measure of magnitude of turbulence intensity in $x$-, $y$ - and $z$-direction in height $z$ is respectively defined as provided in Simiu and Scanlan (1996),

$$
I_{u}=\frac{\sqrt{u^{\prime 2}(z)}}{\bar{u}_{z}} \quad I_{v}=\frac{\sqrt{\overline{v^{\prime 2}(z)}}}{\bar{u}_{z}}, \quad I_{w}=\frac{\sqrt{w^{\prime 2}(z)}}{\bar{u}_{z}},
$$

by applying the Reynolds decomposition, 


$$
u(t)=\bar{u}+u^{\prime}(z), \quad v(t)=\bar{v}+v^{\prime}(z), \quad w(t)=\bar{w}+w^{\prime}(z),
$$

where $\bar{u}, \bar{v}, \bar{w}$ are time-averaged mean wind velocities in the longitudinal $x$-, lateral $y$ - and vertical $z$ direction; $z$ in subscript is the height, while $u^{\prime}, v^{\prime}$ and $w^{\prime}$ are the respective fluctuating wind velocity components.

Turbulent Reynolds shear stress represents a measure for transporting the retarding forces exerted on the wind near the Earth's surface. It is calculated by using the fluctuating velocity correlations $-\rho \overline{u^{\prime} v^{\prime}},-\rho \overline{v^{\prime} w^{\prime}},-\rho \overline{u^{\prime} w^{\prime}}$, where $\rho$ is air density.

The length scale of turbulence represents a comparative measure of the average size of a wind gust (e.g. Holmes, 2007). The length scales of turbulence in $x$-direction related to $u^{\prime}, v^{\prime}, w^{\prime}$ fluctuations are calculated from the time scale of turbulence using autocorrelation functions and assuming the validity of the Taylor's frozen turbulence hypothesis (e.g. ESDU 74030 1976),

$$
T_{i}=\int_{0}^{\infty} R_{i i}(\tau) d \tau
$$

Here, $\mathrm{R}_{i i}$ represents the autocorrelation function, $\tau$ represents incremental time lag and $i=u^{\prime}, v^{\prime}, w^{\prime}$. Taylor's hypothesis of frozen turbulence implies that for mean wind speed $\bar{V}_{z}$ larger than the fluctuating wind velocity component along the $x$-axis, $u(t)$, the turbulence field can be considered to be frozen in space and convected past a point with the mean wind velocity $\bar{V}_{z}$. Assuming the validity of the Taylor's hypothesis of frozen turbulence, turbulence length scales for $i=u^{\prime}, v^{\prime}, w^{\prime}$ components measured along the $x$-axis are defined as (e.g. ESDU 74030 1976),

$$
{ }^{x} L_{i}=T_{i} \cdot \bar{V}_{z}
$$

The measurements analyzed in this study were performed on Pometeno brdo, a location in the hinterland of the town of Split, Croatia (Fig 1a). The exact geographical coordinates of this measurement site are $43^{\circ} 36^{\prime} 28.9^{\prime \prime} \mathrm{N}, 16^{\circ} 28^{\prime} 37.4^{\prime \prime} \mathrm{E}$ with the elevation $618 \mathrm{~m}$ above the sea level. The main hill axis extends from North West to South East. The hill is less steep at the leeward side than on the windward side. In the vicinity of the measurement place there are a few crevices and sinkholes 
127 shrubbery not higher than $2 \mathrm{~m}$. The location is easily accessible by several regional roads.

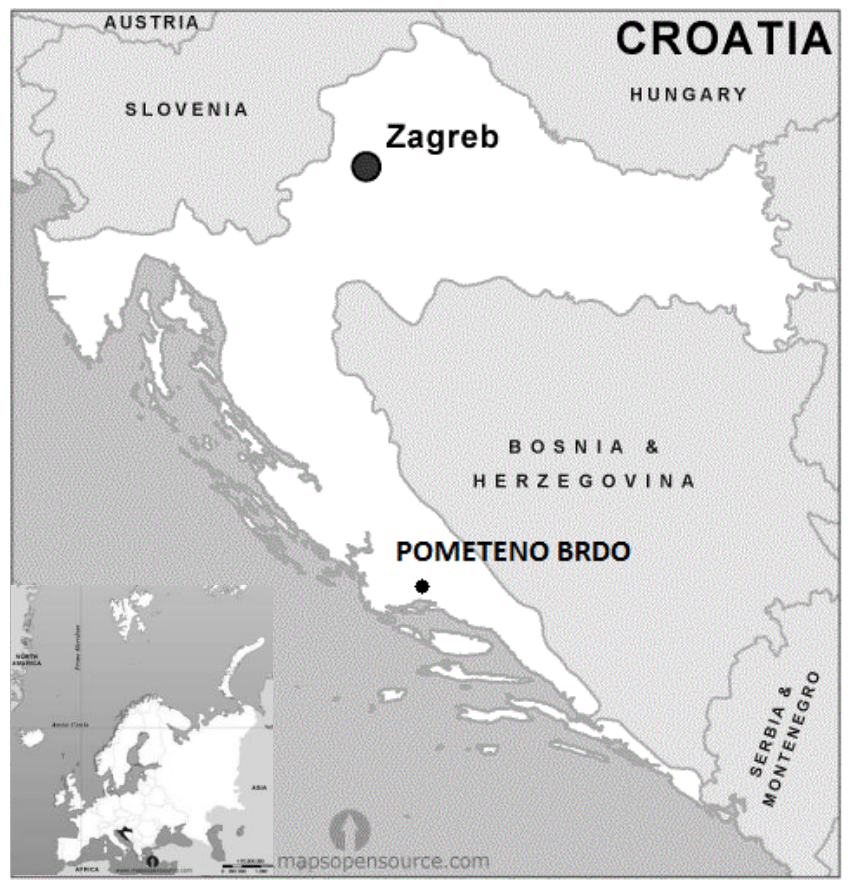

(a)

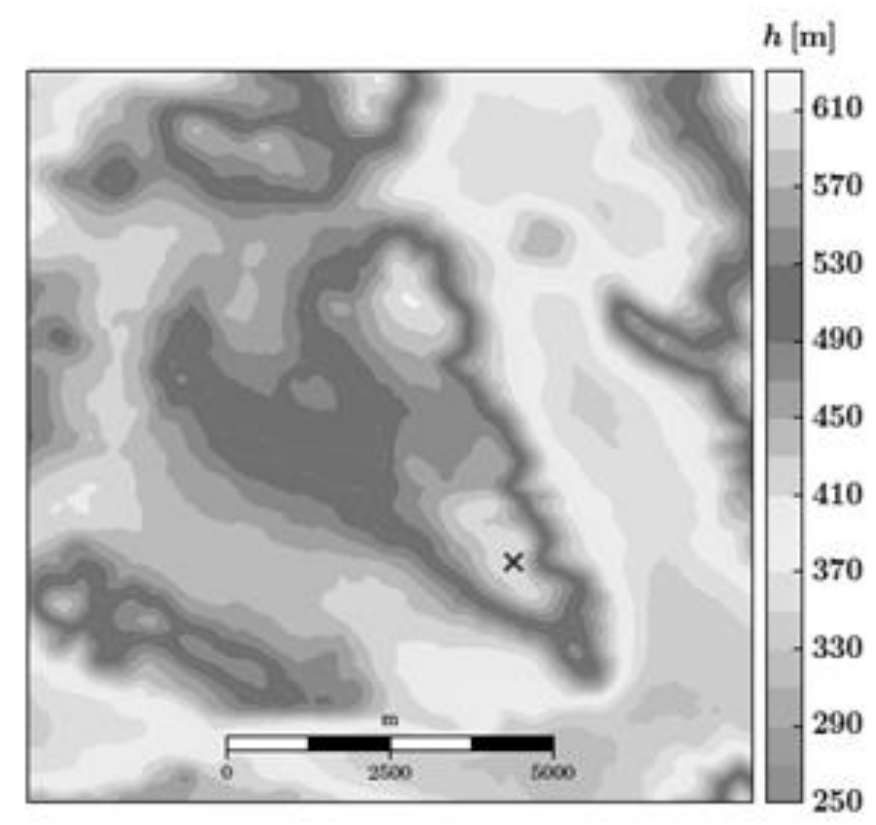

(c)

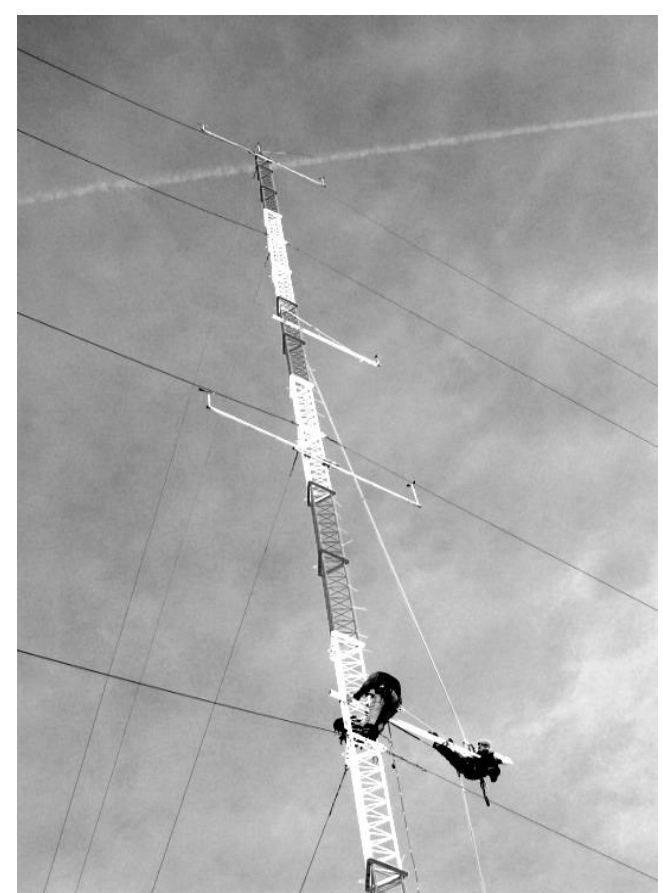

(b)

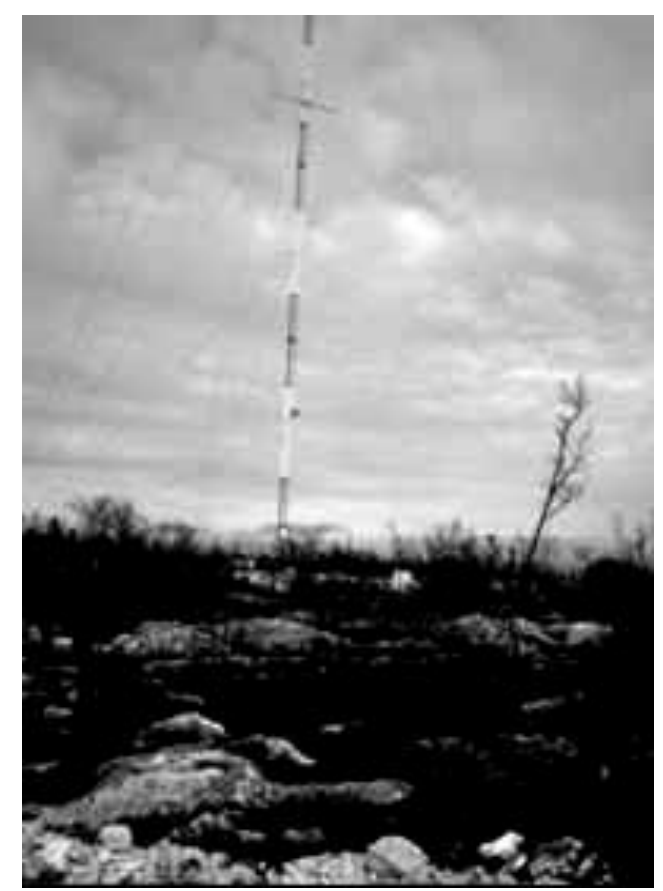

(d)

Fig. 1: (a) Geographic position of the measurement site Pometeno brdo: $\left.43^{\circ} 36^{\prime} 28.9^{\prime \prime} \mathrm{N}, 1^{\circ} 28^{\prime} 37.4^{\prime \prime} \mathrm{E}\right)$. To the 
site. A position of the meteorological tower is denoted with a cross. (d) Vegetation and surroundings of the meteorological tower.

In the time period between April 2010 and June 2011, Eastern, Northern and vertical wind velocity components as well as the ultrasonic temperature were measured using Windmaster Pro (Gill instruments) ultrasonic anemometers on a $60 \mathrm{~m}$ high meteorological tower at three height levels, i.e. $10 \mathrm{~m}, 20 \mathrm{~m}$ and $40 \mathrm{~m}$ (Fig. 1b). Each anemometer was mounted on one end of the $2 \mathrm{~m}$ long aluminum boom whose other end was fixed to the tower in such a way that the anemometers were facing the main Bora wind direction. The measurements were sampled at the frequency of $5 \mathrm{~Hz}$ and collected using Campbell Scientific data logger CR1000, while the whole system was solar powered.

An isolated summertime Bora wind event analyzed in this study lasted from July 24 to 27, 2010, in the overall duration of $62 \mathrm{~h}$. During this particular Bora episode, the wind was long lasting and relatively strong, with mean hourly wind velocities larger than $15 \mathrm{~m} / \mathrm{s}$. During this episode, the lower troposphere was thermally neutrally stratified, Lepri et al. (2014). The weather conditions over most of Europe were largely influenced by low pressure weather systems. However, from the West side of the continent a ridge of high pressure strengthened causing sporadically stormy Bora gusts. The weather conditions on the ground in the area considered were mostly clear sky with good visibility, i.e. the typical Bora conditions (e.g. Grisogono and Belušić 2009). Minimal temperatures in the observed period were between $12{ }^{\circ} \mathrm{C}$ and $20^{\circ} \mathrm{C}$ and maximal between $23{ }^{\circ} \mathrm{C}$ and $27{ }^{\circ} \mathrm{C}$ with relative humidity between $25 \%$ and $60 \%$. The air pressure at the standard mean sea level was slightly reduced with values between 1005 mbar and 1010 mbar.

For this Bora event, turbulence intensity $I_{u}, I_{v}, I_{w}$, Reynolds shear stress components $-\rho \overline{u^{\prime} v^{\prime}},-\rho \overline{v^{\prime} w^{\prime}},-\rho \overline{u^{\prime} w^{\prime}}$ and turbulence length scales, ${ }^{x} L_{u},{ }^{x} L_{v}$ and ${ }^{x} L_{w}$ are analyzed. The selected coordinate system is the one with the $x$-axis aligned along the mean wind direction. Since the anemometers used for the measurements have a specific coordinate system, with abscissa pointed Northwards and ordinate pointed Westwards, the raw data for the two horizontal velocity components are modified accordingly. Because the mean wind direction at $10 \mathrm{~m}$ height was $\approx 54^{\circ}$, at $20 \mathrm{~m}$ height 
$\approx 51^{\circ}$ and $\approx 43^{\circ}$ at $40 \mathrm{~m}$ height, linearly interpolated value at the $25 \mathrm{~m}$ height (the middle height level between $10 \mathrm{~m}$ and $40 \mathrm{~m}$ ) is $49^{\circ}$. Hence, the coordinate system is accordingly rotated for $221^{\circ}$ counter clockwise.

Time-averaged wind velocity is calculated using the moving average approach. To test the sensitivity of Bora turbulence intensity, Reynolds shear stress and turbulence length scales on the choice of the time record length of the moving average, four different time-averaging periods are studied. There are some strong indications that for this particular episode the quasi-periodic Bora pulsations occur at the time period of about 8 min (Belušić et al. 2007, Horvath et al. 2012, Večenaj et al. 2010, 2012). It was also previously reported that the time period of $17 \pm 3$ min represents a suitable turbulence averaging scale (the scale which separates turbulence at small scales from the mean flows at large scales) for this Bora episode, (Magjarević et al. 2011, Večenaj 2012, Lepri et al. 2014). While the appropriate time averaging scale for this particular Bora episode is determined using the ogive approach (e.g. Oncley et al. 1996), other methods can be used for this purpose as well (e.g. Solari et al. 2015).To extend the analysis on this two dynamically important scales and to encompass all the relevant time/length scales, one shorter scale of $5 \mathrm{~min}$, and one longer time scale of $20 \mathrm{~min}$, are assessed as well. Fluctuating wind velocity components are analyzed in the following way. First, the respective time history of the running mean wind velocity is removed from the original time histories, so the velocities are fluctuating around zero wind velocity after performing this action. By normalizing the velocities and velocity correlations in those modified time histories (fluctuating around zero wind velocity) with the respective running mean wind velocity, final values for turbulence intensity and Reynolds shear stress are obtained. This way of analysis is performed as the long-lasting meandering motions of the Bora wind are not considered as a part of the Bora turbulence, so those long-lasting motions are removed in order to allow for unbiased analysis of the Bora turbulence. The velocity time history for each wind component consists of more than $10^{6}$ data points. Figure 2 shows original data for all three velocity components in the modified coordinate system with $x$-axis aligned along the mean Bora direction with superimposed mean wind velocities averaged over the time scale of $17 \mathrm{~min}$. 

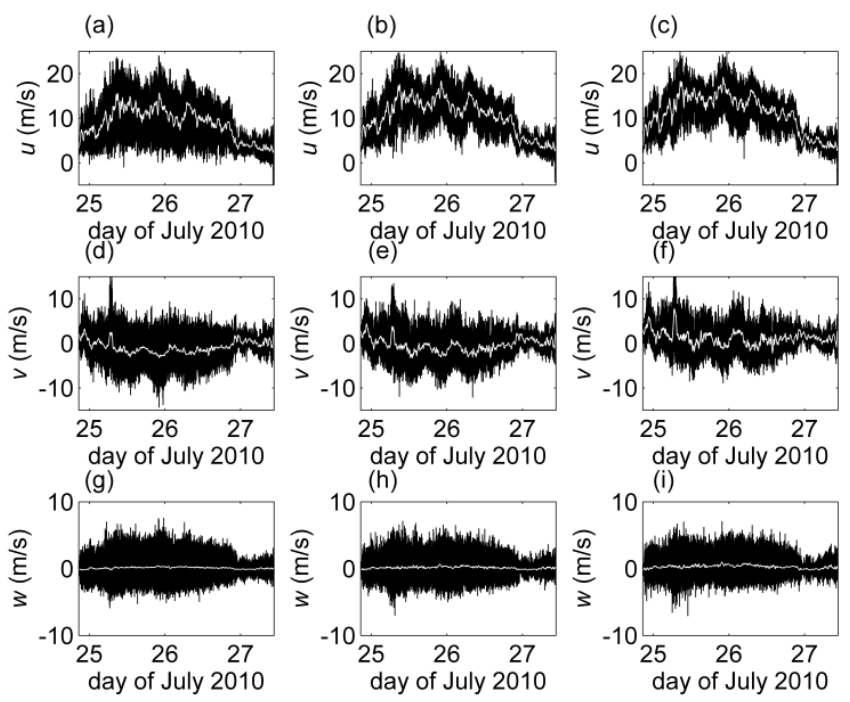

Fig. 2: Original data with superimposed mean wind velocities averaged over the time scale of $17 \mathrm{~min}$ at $10 \mathrm{~m}$ height (left), $20 \mathrm{~m}$ (middle) and $40 \mathrm{~m}$ (right) at the Pometeno brdo tower; longitudinal ( $u$ ), lateral $(v)$ and vertical (w) velocity components, up, middle and down, respectively, recorded from 24 to 27 July 2010.

Turbulence intensity is calculated according to Eq. (1), while the fluctuating wind velocity components are obtained from Eq. (2) using the method described above. The fluctuating wind velocity components are averaged using the same averaging period as for the mean wind velocities and then normalized with the corresponding mean wind velocity value for each time record. The same procedure is applied for all three wind velocity components, for all four averaging periods and for each height level separately.

The Reynolds shear stress components $-\rho \overline{u^{\prime} v^{\prime}},-\rho \overline{v^{\prime} w^{\prime}},-\rho \overline{u^{\prime} w^{\prime}}$ are calculated by applying the moving average on the product of the fluctuating wind velocity values for each height level separately. Four previously specified averaging periods are used in further calculations. The length scales of turbulence in $x$-direction related to $u^{\prime}, v^{\prime}$ and $w^{\prime}$ fluctuating velocity component are calculated using Eq. (3) and Eq. (4). In particular, autocorrelation functions are calculated on point by point sliding blocks of a length that corresponds to the length of the time-averaging period that is used $(5,8,17$ or $20 \mathrm{~min}$ ). For each block, obtained values of the autocorrelation function are numerically integrated providing the value of the corresponding time scale of turbulence. By multiplying this scale with the corresponding mean wind velocity, the length scale of turbulence is obtained. Median values and 
arithmetic mean values of the observed parameters are analyzed, because for this particular Bora event considerable differences between the median and arithmetic mean values are previously reported for the aerodynamic surface roughness length (Lepri et al. 2014).

207

\section{Results and discussion}

In this section, the obtained values for turbulence intensity in $x$-, $y$ - and $z$-direction, three components of Reynolds shear stress and length scales of turbulence in $x$-direction related to the $u^{\prime}, v^{\prime}$ and $w^{\prime}$ fluctuating velocity components are presented.

In Tables 1 - 4 summary statistics for turbulence intensity in $x$-, $y$ - and $z$-directions for the four time averaging periods at $10 \mathrm{~m}, 20 \mathrm{~m}$ and $40 \mathrm{~m}$ height is reported. $\min$.

\begin{tabular}{lccccccccc}
\hline \multirow{2}{*}{ Parameter } & \multicolumn{1}{c}{ Height } \\
\cline { 2 - 9 } & $10 \mathrm{~m}$ & $10 \mathrm{~m}$ & $10 \mathrm{~m}$ & $20 \mathrm{~m}$ & $20 \mathrm{~m}$ & $20 \mathrm{~m}$ & $40 \mathrm{~m}$ & $40 \mathrm{~m}$ & $40 \mathrm{~m}$ \\
\hline Median (-) & $I_{u}$ & $I_{v}$ & $I_{w}$ & $I_{u}$ & $I_{v}$ & $I_{w}$ & $I_{u}$ & $I_{v}$ & $I_{w}$ \\
\hline Arithmetic mean (-) & 0.21 & 0.16 & 0.09 & 0.15 & 0.14 & 0.08 & 0.13 & 0.12 & 0.07 \\
\hline Min. value (-) & 0.21 & 0.18 & 0.10 & 0.16 & 0.15 & 0.08 & 0.16 & 0.15 & 0.08 \\
\hline Max. value (-) & 0.10 & 0.09 & 0.06 & 0.05 & 0.06 & 0.03 & 0.04 & 0.03 & 0.02 \\
\hline Standard deviation (-) & 1.75 & 1.48 & 0.53 & 1.70 & 1.53 & 0.58 & 2.00 & 1.55 & 0.59 \\
\hline
\end{tabular}


Table 2: Summary statistics for turbulence intensity on $10 \mathrm{~m}, 20 \mathrm{~m}$ and $40 \mathrm{~m}$ height for averaging period of 8

223 min.

\begin{tabular}{lccccccccc}
\hline \multirow{2}{*}{ Parameter } & \multicolumn{10}{c}{ Height } \\
\cline { 2 - 10 } & $10 \mathrm{~m}$ & $10 \mathrm{~m}$ & $10 \mathrm{~m}$ & $20 \mathrm{~m}$ & $20 \mathrm{~m}$ & $20 \mathrm{~m}$ & $40 \mathrm{~m}$ & $40 \mathrm{~m}$ & $40 \mathrm{~m}$ \\
\hline & $I_{u}$ & $I_{v}$ & $I_{w}$ & $I_{u}$ & $I_{v}$ & $I_{w}$ & $I_{u}$ & $I_{v}$ & $I_{w}$ \\
\hline Median (-) & 0.21 & 0.17 & 0.09 & 0.15 & 0.14 & 0.08 & 0.13 & 0.13 & 0.07 \\
\hline Arithmetic mean (-) & 0.22 & 0.18 & 0.10 & 0.16 & 0.16 & 0.09 & 0.15 & 0.14 & 0.08 \\
\hline Min. value (-) & 0.12 & 0.10 & 0.06 & 0.07 & 0.08 & 0.03 & 0.05 & 0.04 & 0.03 \\
\hline Max. value (-) & 1.02 & 0.81 & 0.28 & 0.98 & 0.77 & 0.27 & 1.06 & 0.71 & 0.29 \\
\hline Standard deviation (-) & 0.06 & 0.06 & 0.02 & 0.06 & 0.06 & 0.03 & 0.06 & 0.06 & 0.03 \\
\hline
\end{tabular}

224

225 226

227

228

229

230

231

232

233

234

235

236

Table 3: Summary statistics for turbulence intensity on $10 \mathrm{~m}, 20 \mathrm{~m}$ and $40 \mathrm{~m}$ height for averaging period of 17 min.

\begin{tabular}{lcccccccccc}
\hline & \multicolumn{1}{c}{ Height } \\
\cline { 2 - 9 } Parameter & $10 \mathrm{~m}$ & $10 \mathrm{~m}$ & $10 \mathrm{~m}$ & $20 \mathrm{~m}$ & $20 \mathrm{~m}$ & $20 \mathrm{~m}$ & $40 \mathrm{~m}$ & $40 \mathrm{~m}$ & $40 \mathrm{~m}$ \\
\hline & $I_{u}$ & $I_{v}$ & $I_{w}$ & $I_{u}$ & $I_{v}$ & $I_{w}$ & $I_{u}$ & $I_{v}$ & $I_{w}$ \\
\hline Median (-) & 0.22 & 0.17 & 0.09 & 0.16 & 0.15 & 0.08 & 0.14 & 0.14 & 0.07 \\
\hline Arithmetic mean (-) & 0.23 & 0.19 & 0.10 & 0.17 & 0.17 & 0.09 & 0.15 & 0.15 & 0.08 \\
\hline Min. value (-) & 0.14 & 0.12 & 0.06 & 0.09 & 0.09 & 0.04 & 0.06 & 0.06 & 0.03 \\
\hline Max. value (-) & 0.76 & 0.70 & 0.22 & 0.70 & 0.66 & 0.21 & 0.69 & 0.64 & 0.23 \\
\hline Standard deviation (-) & 0.05 & 0.07 & 0.02 & 0.05 & 0.06 & 0.03 & 0.05 & 0.06 & 0.03 \\
\hline
\end{tabular}



$\min$.

\begin{tabular}{lccccccccc}
\hline \multirow{2}{*}{ Parameter } & \multicolumn{1}{c}{ Height } \\
\cline { 2 - 10 } & $10 \mathrm{~m}$ & $10 \mathrm{~m}$ & $10 \mathrm{~m}$ & $20 \mathrm{~m}$ & $20 \mathrm{~m}$ & $20 \mathrm{~m}$ & $40 \mathrm{~m}$ & $40 \mathrm{~m}$ & $40 \mathrm{~m}$ \\
\hline & $I_{u}$ & $I_{v}$ & $I_{w}$ & $I_{u}$ & $I_{v}$ & $I_{w}$ & $I_{u}$ & $I_{v}$ & $I_{w}$ \\
\hline Median (-) & 0.22 & 0.17 & 0.09 & 0.16 & 0.15 & 0.08 & 0.14 & 0.14 & 0.07 \\
\hline Arithmetic mean (-) & 0.23 & 0.19 & 0.10 & 0.17 & 0.17 & 0.09 & 0.16 & 0.15 & 0.08 \\
\hline Min. value (-) & 0.14 & 0.12 & 0.06 & 0.09 & 0.09 & 0.04 & 0.06 & 0.06 & 0.03 \\
\hline Max. value (-) & 0.67 & 0.65 & 0.20 & 0.62 & 0.63 & 0.20 & 0.61 & 0.60 & 0.23 \\
\hline Standard deviation (-) & 0.05 & 0.07 & 0.02 & 0.05 & 0.06 & 0.03 & 0.05 & 0.06 & 0.03 \\
\hline
\end{tabular}
and 0.22 on $10 \mathrm{~m}$ height, between 0.15 and 0.16 on $20 \mathrm{~m}$ height and between 0.13 and 0.14 on $40 \mathrm{~m}$ height. Medians of turbulence intensity values in $y$-direction for different averaging periods are between 0.16 and 0.17 on $10 \mathrm{~m}$ height, between 0.14 and 0.15 on $20 \mathrm{~m}$ height and between 0.12 and 0.14 on $40 \mathrm{~m}$ height, while medians of turbulence intensity values in $z$-direction vary between 0.09 on $10 \mathrm{~m}$ height, 0.08 on $20 \mathrm{~m}$ height and 0.07 on $40 \mathrm{~m}$ height. From Tables $1-4$ it can be observed that the median values agree well with the corresponding arithmetic mean values, while it can be noticed that both the median and the arithmetic mean values for all three components slightly increase for longer averaging periods. The standard deviation, which defines data variations from the average or expected value (e.g. Wilks 1995), with the observed values between 0.02 and 0.07 , for all intensity components and for all four averaging periods, indicates that the data differs considerably from the corresponding average value. Significant variations of the Bora wind higher-order statistical moments, corresponding to the Bora characteristic gustiness (e.g. Grisogono and Belušić 2009, Kozmar et al. 2012a, Večenaj et al. 2012), are the typical properties of the general Bora flows (Poje 1992, Belušić et al. 2006, 2007). 
In order to investigate the dependence of $I_{u}, I_{v}$ and $I_{w}$ on the average wind velocity, the time series for the turbulence intensity components for time averaging period $17 \mathrm{~min}$ at all three height levels are presented in Figs. 3 - 5. The time series for other three time averaging perods indicate the same trends and are therefore not reported.

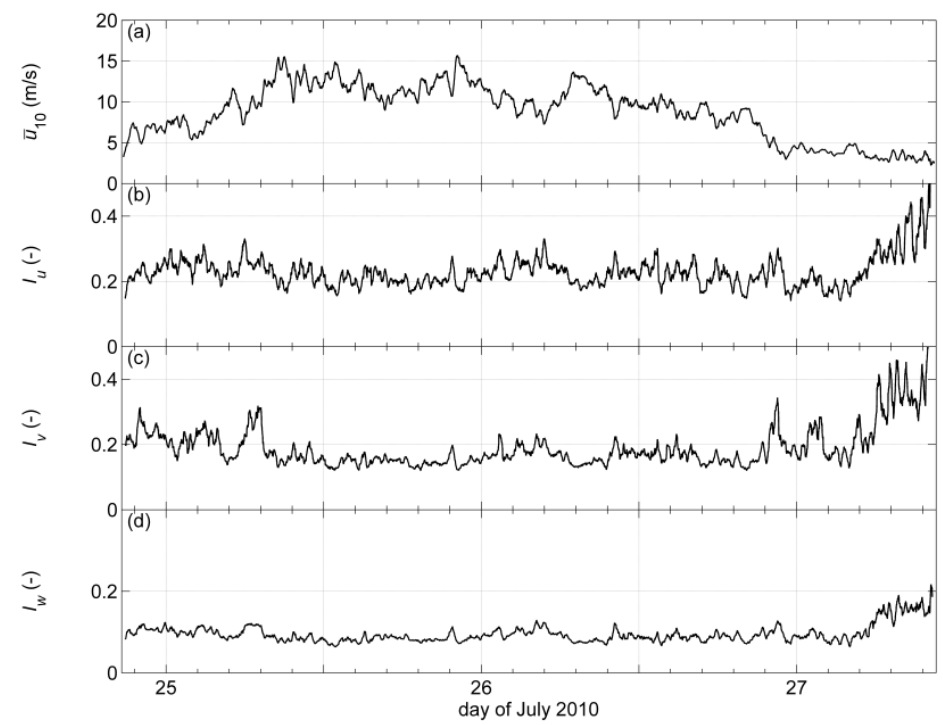
height; time series of (b) turbulence intensity in $x$-direction (c) turbulence intensity in $y$-direction (d) turbulence intensity in $z$-direction for averaging period of $17 \mathrm{~min}$ at $10 \mathrm{~m}$ height.

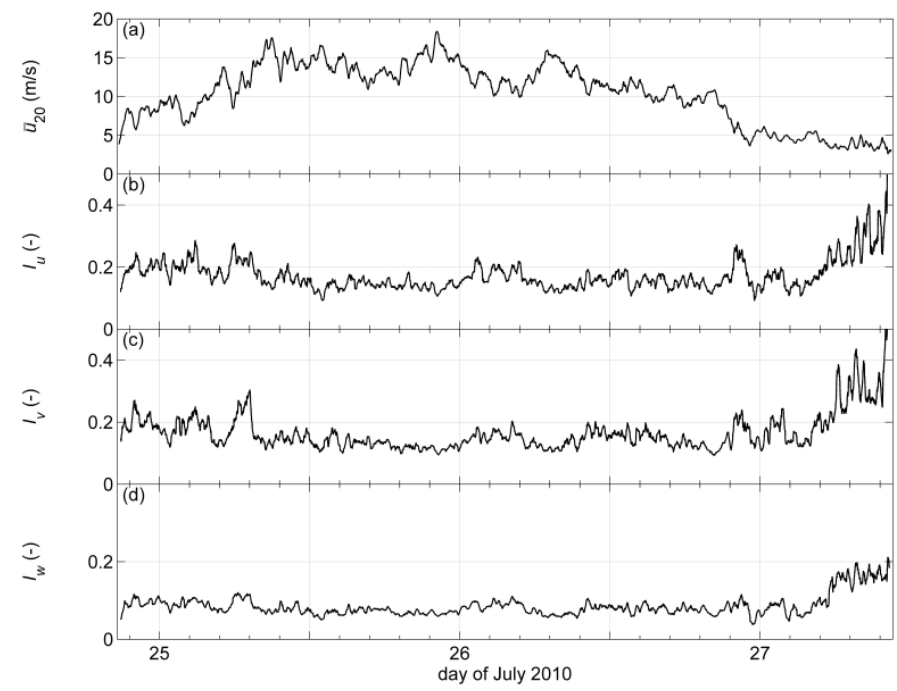



height; time series of (b) turbulence intensity in $x$-direction (c) turbulence intensity in $y$-direction (d) turbulence intensity in $z$-direction for averaging period of $17 \mathrm{~min}$ at $20 \mathrm{~m}$ height.

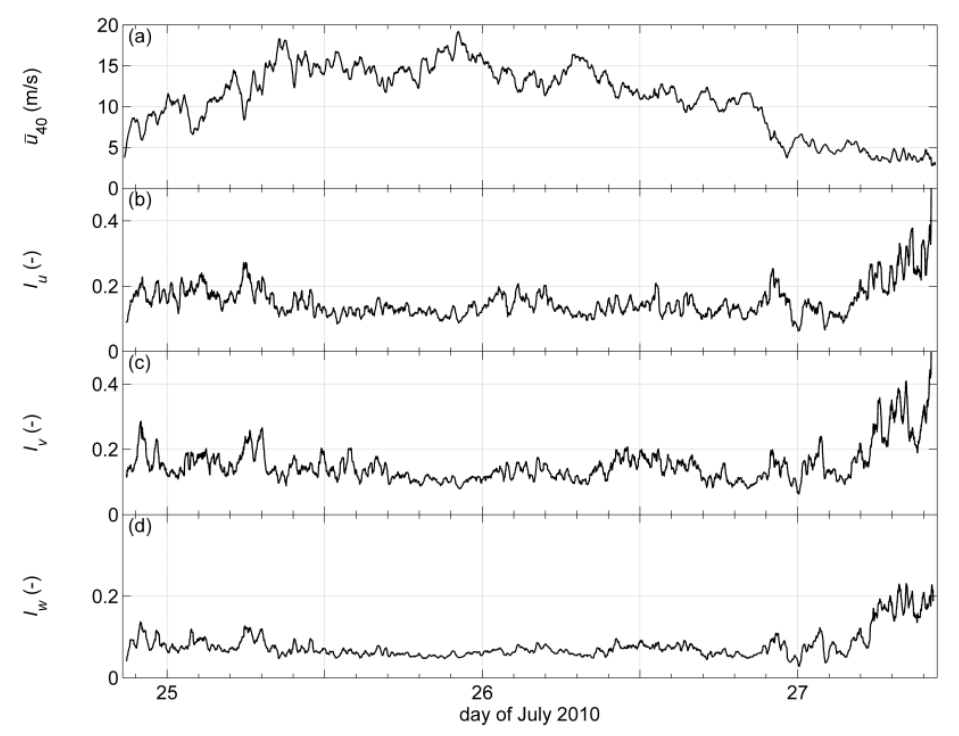

Fig. 5: (a) Mean wind velocity in the main (x) wind direction averaged over the time scale of $17 \mathrm{~min}$ at $40 \mathrm{~m}$ height; time series of (b) turbulence intensity in $x$-direction (c) turbulence intensity in $y$-direction (d) turbulence intensity in $z$-direction for averaging period of $17 \mathrm{~min}$ at $40 \mathrm{~m}$ height.

These plots confirm the features already determined by the statistical methods used (Tables 1-4). The vertical turbulence intensity component is in average two times smaller than the two horizontal components for all averaging periods and on all height levels. Another interesting characteristic is that for the mean wind velocities larger than $\sim 5 \mathrm{~m} / \mathrm{s}$ the turbulence intensity components remain nearly constant during the time record, i.e. they are not that strongly dependent on the varying 17-min running mean wind velocity. In particular, during the period with mean wind velocities larger than 5 $\mathrm{m} / \mathrm{s}$, the average wind velocity deviation is around $30 \%$ from the the mean wind velocity calculated through the entire time record of $62 \mathrm{~h}$. At the same time, the respective average deviation of $I_{u}, I_{v}$ and $I_{w}$ is between $14 \%$ and $24 \%$ with respect to the corresponding mean turbulent intensity component calculated through the entire time record, $62 \mathrm{~h}$. No clear day-to-night trends can be observed in the behaviour of the observed turbulence intensity components. Regarding the wind speeds less than 5 
$\mathrm{m} / \mathrm{s}$, these may be related to either Bora rapid and short tranisence, or to a totally different, thermally driven, katabatic flow type (Grisogono and Belušić 2009, Grisogono et al. 2015).

Bora turbulence intensites, $I_{u}, I_{v}$ and $I_{w}$ do not completely agree with the equation,

$$
I_{u}: I_{v}: I_{w}=1: 0.75: 0.5,
$$

suggested by Counihan (1975), nor with the equation proposed by Holmes (2007),

$$
I_{u}: I_{v}: I_{w}=1: 0.88: 0.55,
$$

287 both originaly provided for the atmospheric boundary layer (ABL). In particular, Table 5 shows turbulence intensity ratios obtained for this Bora event. Although it can be noticed that the ratio between $I_{w}$ and $I_{u}$ agrees well with Eqs. (5) and (6),on the other hand, the values for $I_{v}$ and $I_{u}$ are quite similar, particularly higher above the ground. This indicates that lateral pulsations of the Bora flow are stronger if compared to the longitudinal velocity fluctuations typical for the usual ABL. The ratios between the various turbulence intensity components for the time averaging periods of $5 \mathrm{~min}, 8 \mathrm{~min}$ and $20 \mathrm{~min}$ are not reported (Večenaj 2012), as they are basically the same as for the time averaging period of $17 \mathrm{~min}$.

Table 5: Turbulence intensity ratios for the time averaging period of $17 \mathrm{~min}$ on the three height levels.

\begin{tabular}{ccc}
\hline Height & $I_{v} / I_{u}$ & $I_{w} / I_{u}$ \\
\hline $10 \mathrm{~m}$ & 0.84 & 0.45 \\
\hline $20 \mathrm{~m}$ & 0.95 & 0.50 \\
\hline $40 \mathrm{~m}$ & 1.00 & 0.50 \\
\hline
\end{tabular}

To additionally investigate the trends in turbulence intensity with increasing height, vertical $I_{u}, I_{v}, I_{w}$ profiles for the time averaging period of $17 \mathrm{~min}$ are presented in Fig. 6.The trends observed in respective vertical turbulence intensity profiles for other time-averaging periods are basically the same. The data is compared with international standards ESDU 85020 (1985), ISO 4354 (1997), EN 1991 Eurocode 1 (2005), ASCE 7-05 (2006) and AIJ (2006). 

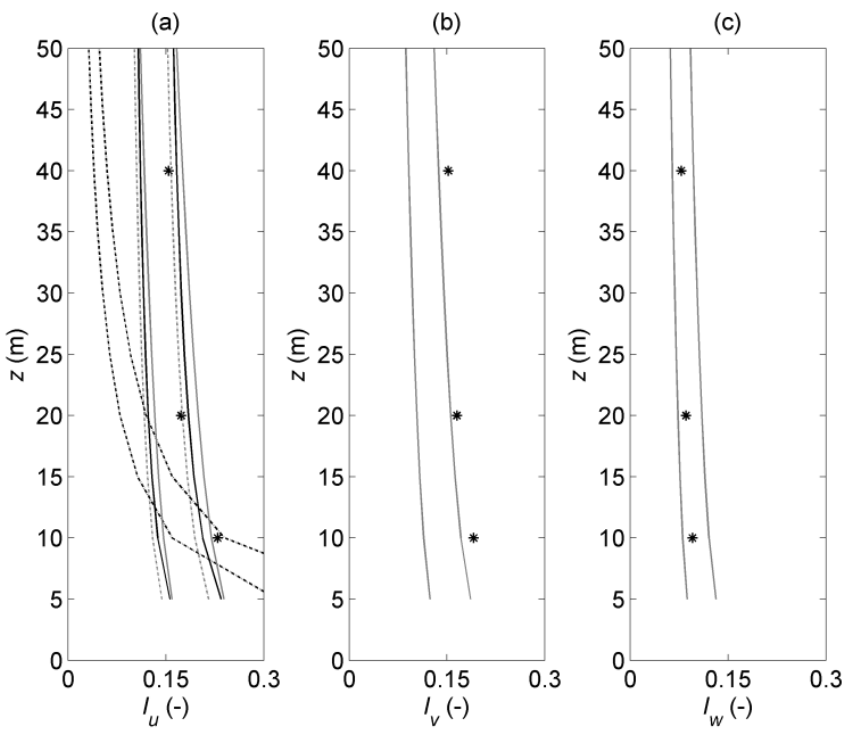

Fig 6: Vertical profiles of observed turbulence intensity for the averaging period of 17 min in the (a) $x$-, (b) $y$ and (c) $z$-direction calculated through the entire time record and compared with the values in international standards with the tolerance range of $\pm 20 \%$. Legend: star is average turbulence intensity, grey solid line is ESDU 85020 (1985) for $z_{0}=0.03 \mathrm{~m}$, black solid line is ISO 4354 (1997) and EN 1991 Eurocode 1 (2005), black dotted line is ASCE 7-05 (2006), grey dotted line is AIJ (2006).

The values reported as stars in Fig. 6 represent average values calculated through the entire time record, meaning one value in each height for the entire recording period. It can be observed that for this particular Bora episode the obtained values for all three intensity components decrease with increasing height, in agreement with atmospheric physics (e.g. Stull, 1988). $I_{u}$ and $I_{w}$ agree well with the values proposed in ESDU 85020 (1985) for surface roughness length $z_{0}=0.03 \mathrm{~m}$, which corresponds to an open country with a few trees and hedges and isolated buildings. This type of terrain is a good description of the terrain characteristics at the measuring site Pometeno brdo. The values obtained for $I_{v}$ are a bit larger than the recommended values. The values obtained for $I_{u}$ agree reasonably well with the values recommended in ISO 4354 (1997), EN 1991 Eurocode 1 (2005), AIJ (2006) and ASCE 7-05 (2006) as well.

In Tables 6-9the statistical parameters for Reynolds shear stress are presented. 

min.

\begin{tabular}{lccccccccc}
\hline \multirow{2}{*}{ Parameter } & \multicolumn{7}{c}{ Height } \\
\cline { 2 - 9 } & $10 \mathrm{~m}$ & $10 \mathrm{~m}$ & $10 \mathrm{~m}$ & $20 \mathrm{~m}$ & $20 \mathrm{~m}$ & $20 \mathrm{~m}$ & $40 \mathrm{~m}$ & $40 \mathrm{~m}$ & $40 \mathrm{~m}$ \\
\hline & $\frac{-\overline{u^{\prime} w^{\prime}}}{\bar{u}_{10}^{2}}$ & $\frac{-\overline{u^{\prime} v^{\prime}}}{\bar{u}_{10}^{2}}$ & $\frac{-\overline{v^{\prime} w^{\prime}}}{\bar{u}_{10}^{2}}$ & $-\frac{\bar{u}^{\prime} w^{\prime}}{\bar{u}_{20}^{2}}$ & $-\frac{\bar{u}^{\prime} v^{\prime}}{\bar{u}_{20}^{2}}$ & $-\frac{\bar{v}^{\prime} w^{\prime}}{\bar{u}_{20}^{2}}$ & $-\frac{\bar{u}^{\prime} w^{\prime}}{\bar{u}_{40}^{2}}$ & $-\frac{u^{\prime} v^{\prime}}{\bar{u}^{2}}$ & $-\frac{v^{\prime} w^{\prime}}{\bar{u}_{40}^{2}}$ \\
\hline Median (-) & 0.005 & 0.002 & 0.002 & 0.002 & -0.001 & 0.004 & 0.002 & -0.000 & 0.002 \\
\hline Arithmetic mean (-) & 0.006 & 0.003 & 0.003 & 0.003 & -0.000 & 0.005 & 0.002 & 0.000 & 0.003 \\
\hline Min. value (-) & -0.073 & -0.123 & -0.010 & -0.044 & -0.071 & -0.006 & -0.147 & -0.073 & -0.014 \\
\hline Max. value (-) & 0.057 & 1.673 & 0.173 & 0.129 & 1.597 & 0.192 & 0.197 & 1.922 & 0.143 \\
\hline Standard deviation (-) & 0.004 & 0.035 & 0.005 & 0.004 & 0.031 & 0.006 & 0.005 & 0.033 & 0.006 \\
\hline
\end{tabular}
323

324 Table 7: Summary statistics for Reynolds shear stress on $10 \mathrm{~m}, 20 \mathrm{~m}$ and $40 \mathrm{~m}$ height for averaging period of 8 $325 \min$.

\begin{tabular}{|c|c|c|c|c|c|c|c|c|c|}
\hline \multirow{2}{*}{ Parameter } & \multicolumn{9}{|c|}{ Height } \\
\hline & $10 \mathrm{~m}$ & $10 \mathrm{~m}$ & $10 \mathrm{~m}$ & $20 \mathrm{~m}$ & $20 \mathrm{~m}$ & $20 \mathrm{~m}$ & $40 \mathrm{~m}$ & $40 \mathrm{~m}$ & $40 \mathrm{~m}$ \\
\hline & $-\overline{u^{\prime} w^{\prime}}$ & $-\overline{u^{\prime} v^{\prime}}$ & $-\overline{v^{\prime} w^{\prime}}$ & $\overline{u^{\prime} w^{\prime}}$ & $\overline{u^{\prime} v^{\prime}}$ & $\overline{v^{\prime} w^{\prime}}$ & $\overline{u^{\prime} w^{\prime}}$ & $\overline{u^{\prime} v^{\prime}}$ & $\overline{v^{\prime} w^{\prime}}$ \\
\hline & $\overline{\bar{u}_{10}^{2}}$ & $\overline{\bar{u}_{10}{ }^{2}}$ & $\overline{\bar{u}_{10}{ }^{2}}$ & $\bar{u}_{20}^{2}$ & $\bar{u}_{20}^{2}$ & $\bar{u}_{20}^{2}$ & $\bar{u}_{40}^{2}$ & $\bar{u}_{40}^{2}$ & $\overline{\bar{u}}_{40}{ }^{2}$ \\
\hline Median (-) & 0.006 & 0.003 & 0.002 & 0.002 & -0.001 & 0.004 & 0.002 & -0.000 & 0.002 \\
\hline Arithmetic mean (-) & 0.006 & 0.003 & 0.003 & 0.003 & -0.000 & 0.005 & 0.002 & 0.000 & 0.003 \\
\hline Min. value (-) & -0.011 & -0.082 & -0.009 & -0.017 & -0.050 & -0.007 & -0.028 & -0.051 & -0.011 \\
\hline Max. value (-) & 0.035 & 0.516 & 0.044 & 0.063 & 0.461 & 0.047 & 0.056 & 0.437 & 0.054 \\
\hline Standard deviation (-) & 0.003 & 0.020 & 0.003 & 0.003 & 0.017 & 0.004 & 0.003 & 0.016 & 0.005 \\
\hline
\end{tabular}

334 Table 8: Summary statistics for Reynolds shear stress on $10 \mathrm{~m}, 20 \mathrm{~m}$ and $40 \mathrm{~m}$ height for averaging period of 17 335 min. 


\begin{tabular}{|c|c|c|c|c|c|c|c|c|c|}
\hline \multirow{2}{*}{ Parameter } & \multicolumn{9}{|c|}{ Height } \\
\hline & $10 \mathrm{~m}$ & $10 \mathrm{~m}$ & $10 \mathrm{~m}$ & $20 \mathrm{~m}$ & $20 \mathrm{~m}$ & $20 \mathrm{~m}$ & $40 \mathrm{~m}$ & $40 \mathrm{~m}$ & $40 \mathrm{~m}$ \\
\hline & $-\overline{u^{\prime} w^{\prime}}$ & $-\overline{u^{\prime} v^{\prime}}$ & $-\overline{v^{\prime} w^{\prime}}$ & $\overline{u^{\prime} w^{\prime}}$ & $\overline{u^{\prime} v^{\prime}}$ & $\overline{v^{\prime} w^{\prime}}$ & $\overline{u^{\prime} w^{\prime}}$ & $\overline{u^{\prime} v^{\prime}}$ & $\overline{v^{\prime} w^{\prime}}$ \\
\hline & $\overline{\bar{u}_{10}^{2}}$ & $\overline{\bar{u}_{10}{ }^{2}}$ & $\overline{\bar{u}_{10}^{2}}$ & $\overline{\bar{u}_{20}^{2}}$ & $\bar{u}_{20}^{2}$ & $\bar{u}_{20}^{2}$ & $\bar{u}_{40}^{2}$ & $\overline{\bar{u}}_{40}^{2}$ & $\bar{u}_{40}^{2}$ \\
\hline Median (-) & 0.006 & 0.004 & 0.002 & 0.003 & 0.000 & 0.004 & 0.002 & 0.000 & 0.002 \\
\hline Arithmetic mean (-) & 0.006 & 0.004 & 0.003 & 0.003 & 0.001 & 0.005 & 0.002 & 0.001 & 0.003 \\
\hline Min. value (-) & -0.000 & -0.039 & -0.001 & -0.013 & -0.032 & -0.003 & -0.022 & -0.045 & -0.007 \\
\hline Max. value (-) & 0.024 & 0.297 & 0.029 & 0.023 & 0.269 & 0.035 & 0.022 & 0.235 & 0.045 \\
\hline Standard deviation (-) & 0.003 & 0.017 & 0.003 & 0.003 & 0.015 & 0.004 & 0.003 & 0.013 & 0.004 \\
\hline
\end{tabular}

336

337 Table 9: Summary statistics for Reynolds shear stress on 10 m, $20 \mathrm{~m}$ and $40 \mathrm{~m}$ height for averaging period of 20 $338 \mathrm{~min}$.

\begin{tabular}{|c|c|c|c|c|c|c|c|c|c|}
\hline \multirow{2}{*}{ Parameter } & \multicolumn{9}{|c|}{ Height } \\
\hline & $10 \mathrm{~m}$ & $10 \mathrm{~m}$ & $10 \mathrm{~m}$ & $20 \mathrm{~m}$ & $20 \mathrm{~m}$ & $20 \mathrm{~m}$ & $40 \mathrm{~m}$ & $40 \mathrm{~m}$ & $40 \mathrm{~m}$ \\
\hline & $\overline{-u^{\prime} w^{\prime}}$ & $-\overline{u^{\prime} v^{\prime}}$ & $-\overline{v^{\prime} w^{\prime}}$ & $\overline{u^{\prime} w^{\prime}}$ & $\overline{u^{\prime} v^{\prime}}$ & $\overline{v^{\prime} w^{\prime}}$ & $\overline{u^{\prime} w^{\prime}}$ & $\overline{u^{\prime} v^{\prime}}$ & $\overline{v^{\prime} w^{\prime}}$ \\
\hline & $\overline{\bar{u}_{10}^{2}}$ & $\overline{\bar{u}_{10}^{2}}$ & $\overline{\bar{u}_{10}^{2}}$ & $\overline{\bar{u}_{20}^{2}}$ & $\overline{\bar{u}}_{20}^{2}$ & $\overline{\bar{u}_{20}^{2}}$ & $\bar{u}_{40}^{2}$ & $\overline{\bar{u}}_{40}^{2}$ & $\bar{u}_{40}^{2}$ \\
\hline Median (-) & 0.006 & 0.004 & 0.002 & 0.003 & 0.000 & 0.004 & 0.002 & 0.000 & 0.002 \\
\hline Arithmetic mean (-) & 0.006 & 0.005 & 0.003 & 0.003 & 0.001 & 0.005 & 0.002 & 0.001 & 0.003 \\
\hline Min. value (-) & -0.004 & -0.042 & -0.000 & -0.014 & -0.038 & -0.003 & -0.022 & -0.042 & -0.007 \\
\hline Max. value (-) & 0.025 & 0.235 & 0.028 & 0.022 & 0.210 & 0.032 & 0.023 & 0.177 & 0.037 \\
\hline Standard deviation (-) & 0.003 & 0.015 & 0.003 & 0.003 & 0.013 & 0.004 & 0.003 & 0.010 & 0.004 \\
\hline
\end{tabular}

340 It can be observed that the median values for the dominant turbulent Reynolds shear stress component

341 (since $\rho \approx$ const here) $-\overline{u^{\prime} w^{\prime}}$ normalized with the respective wind velocity in mean $(x)$ direction range

342 between 0.005 and 0.006 at $10 \mathrm{~m}$ height, between 0.002 and 0.003 at $20 \mathrm{~m}$ height and around 0.002

343 at40 m height. The median values for the normalized turbulent Reynolds stress component $-\overline{u^{\prime} v^{\prime}}$ range

344 between 0.002 and 0.004 at $10 \mathrm{~m}$ height, between -0.001 and 0.000 at $20 \mathrm{~m}$ height and around 0.000 at

$34540 \mathrm{~m}$ height. The median values for the normalized $-\overline{v^{\prime} w^{\prime}}$ turbulent Reynolds stress component are

346 scattered around 0.002 at the $10 \mathrm{~m}$ height, 0.004 at $20 \mathrm{~m}$ height and 0.002 at $40 \mathrm{~m}$ height. For all three 
turbulent Reynolds shear stress components it can be noticed that the median value and the arithmetic

348 mean value agree well. The normalized $-\overline{u^{\prime} w^{\prime}}$ and $-\overline{u^{\prime} v^{\prime}}$ components decrease with height. The 349 standard deviations, which define data variations for the normalized $-\overline{u^{\prime} w^{\prime}}$ and $-\overline{v^{\prime} w^{\prime}}$ components, with the observed values between 0.003 and 0.006 for all four averaging periods, indicate that the data differ moderately from the corresponding average value. At the same time the standard deviations for 352 the normalized $-\overline{u^{\prime} v^{\prime}}$ component are significantly larger, with values ranging from 0.010 to 0.035 ,indicatinga larger dispersion in comparison with two other Reynolds shear stress components.

To analyze the Reynolds shear stress dependence on the average wind velocity, the respective time series for the averaging period of 17 min are presented in Figs. 7 - 9. The time series for the averaging time periods of $5 \mathrm{~min}, 8 \mathrm{~min}$ and $20 \mathrm{~min}$ are not reported because the trends are basically the same.

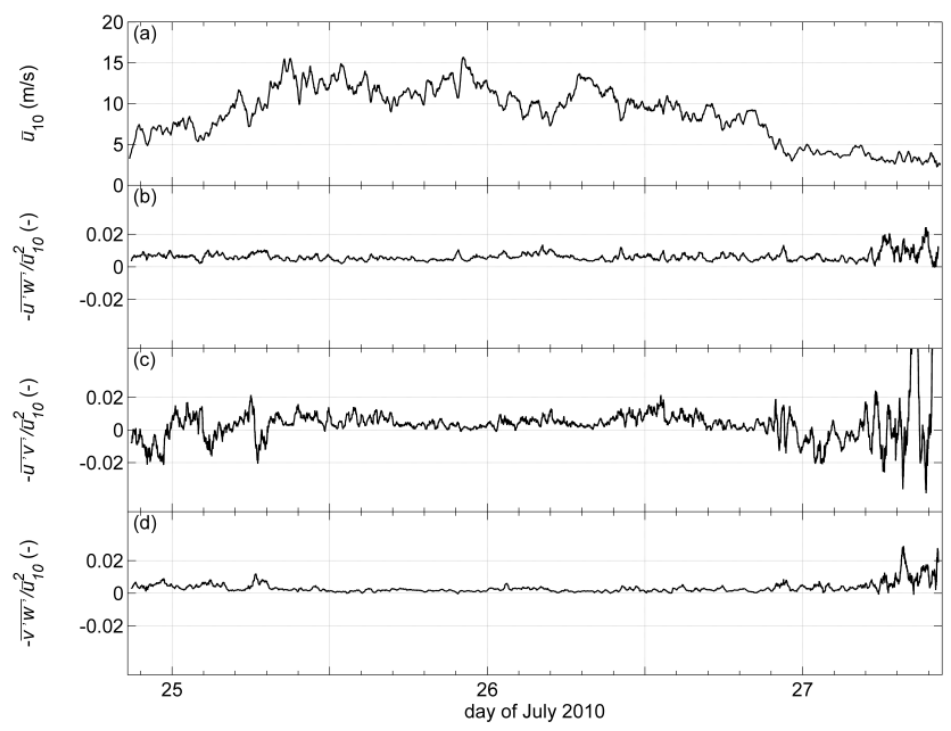

Fig. 7: (a) Mean wind velocity in the main $(x)$ wind direction averaged over the time scale of $17 \mathrm{~min}$ at $10 \mathrm{~m}$ 


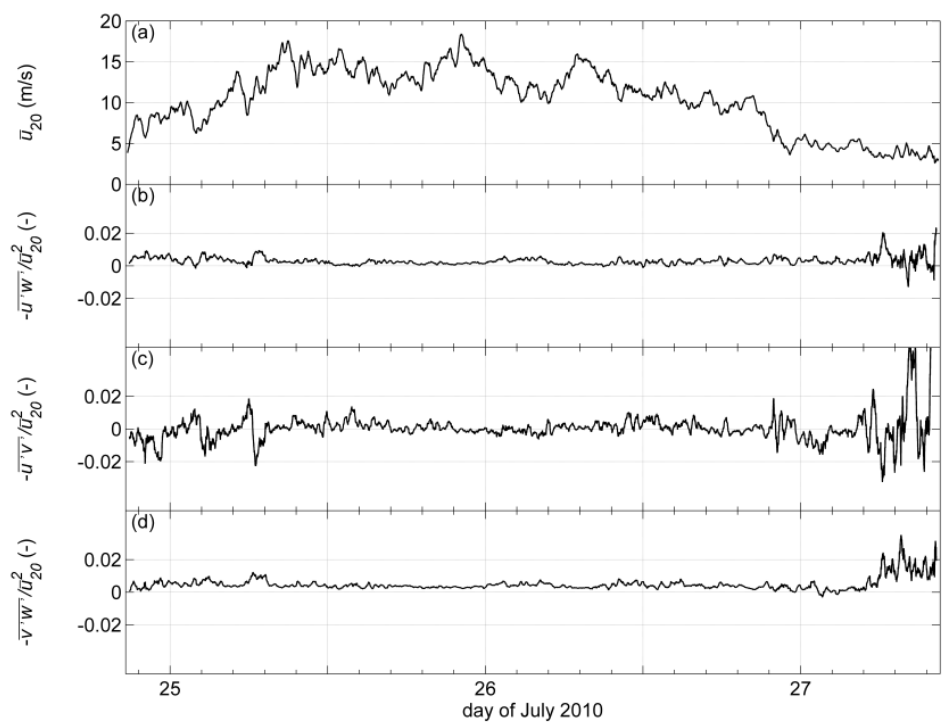

362

363 Fig. 8: (a) Mean wind velocity in the main (x) wind direction averaged over the time scale of $17 \mathrm{~min}$ at $20 \mathrm{~m}$ height; time series of the calculated Reynolds shear stress components (b) $-\overline{u^{\prime} w^{\prime}}$, (c) $-\overline{u^{\prime} v^{\prime}}$, (d) $-\overline{v^{\prime} w^{\prime}}$ all normalized with mean wind velocity in the main $(x)$ wind direction at $20 \mathrm{~m}$ height for the time averaging period

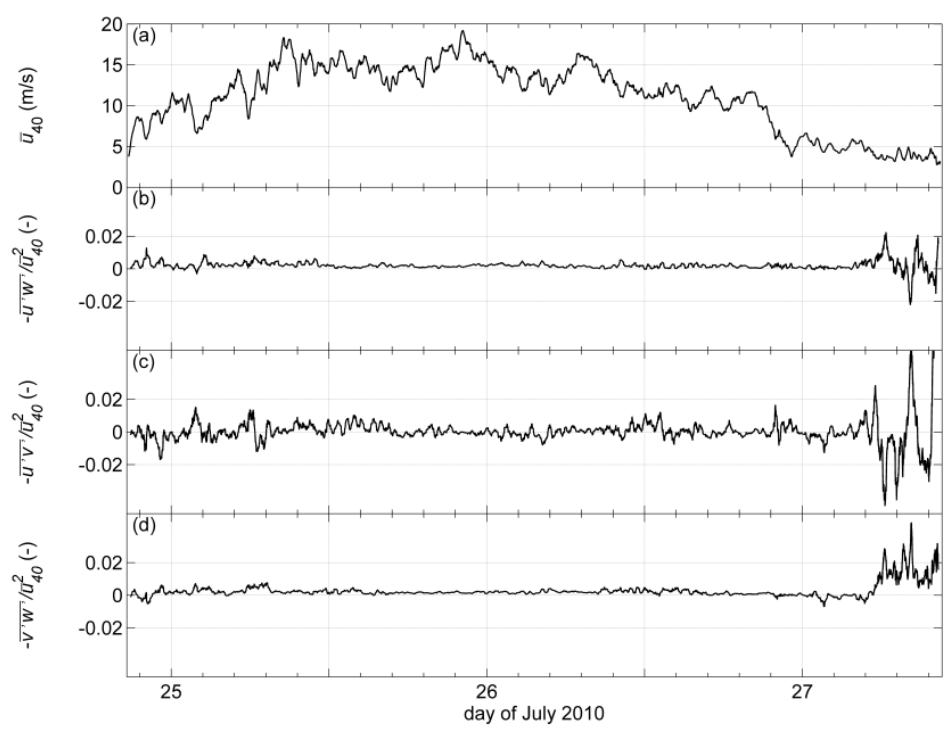

Fig. 9: (a) Mean wind velocity in the main $(x)$ wind direction averaged over the time scale of $17 \mathrm{~min}$ at $40 \mathrm{~m}$ height; time series of calculated Reynolds shear stress components (b) $-\overline{u^{\prime} w^{\prime}}$, (c) $-\overline{u^{\prime} v^{\prime}}$, (d) $-\overline{v^{\prime} w^{\prime}}$ all normalized with mean wind velocity in the main $(x)$ wind direction at $40 \mathrm{~m}$ height for the time averaging period of $17 \mathrm{~min}$. 
The graphical representation of the three Reynolds shear stress components confirms the statistics

374

375

376

377

378

379 presented in Tables 6 - 9. In particular, the $-\overline{u^{\prime} w^{\prime}}$ component is the strongest one, while the $-\overline{u^{\prime} v^{\prime}}$ component shows the largest dispersion of the data. Similarly as for the turbulence intensity, the Reynolds shear stress components on all three heights remain nearly constant during the time record for the mean wind velocities larger than $\sim 5 \mathrm{~m} / \mathrm{s}$. The trends remain the same during the day and the night.

Furthermore, the vertical profiles of the Reynolds shear stress components normalized with the mean wind velocity at the respective height for the averaging period of 17 min are presented in Fig. 10. The trends in vertical profiles of the Reynolds shear stress components for the other time averaging periods are the same as those reported in Fig. 10 and therefore are not shown.

(a)

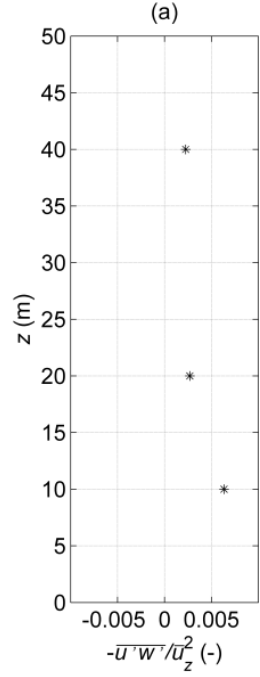

(b)

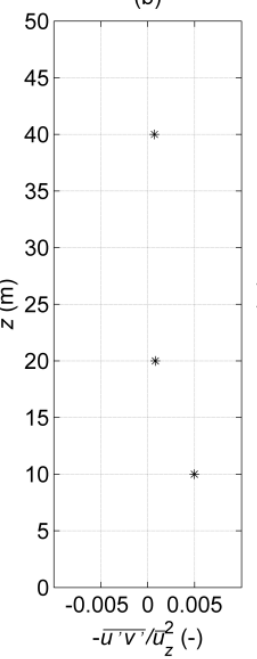

(c)

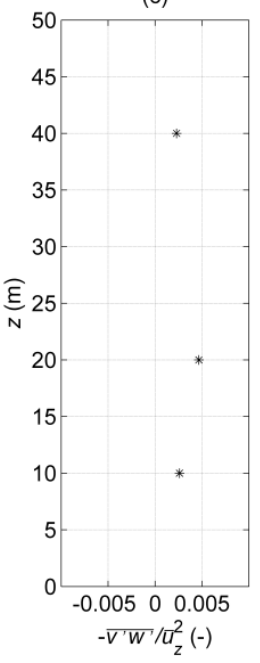

Fig. 10: Vertical profiles of the (a) $-\overline{u^{\prime} w^{\prime}}$, (b) $-\overline{u^{\prime} v^{\prime}}$, (c) $-\overline{v^{\prime} w^{\prime}}$ Reynolds shear stress components for the averaging period of 17 min calculated through the entire time record and normalized using the 17 min average wind velocity in the main $(x)$ wind direction at the corresponding height for each height level.

Vertical profiles of the Reynolds shear stress indicate decreasing values with increasing height for the $-\overline{u^{\prime} w^{\prime}}$ and $-\overline{u^{\prime} v^{\prime}}$ components. Nearly identical values for the $-\overline{u^{\prime} w^{\prime}}$ component at $20 \mathrm{~m}$ and $40 \mathrm{~m}$ height indicate a likely existence of the Prandtl constant-flux layer. At the same time, an interesting 
391 and unexpected behavior can be observed for the $-\overline{v^{\prime} w^{\prime}}$ component at $20 \mathrm{~m}$ height indicating a strong 392 momentum exchange between the lateral and vertical velocity fluctuations. This is possibly due to the very local characteristics (e.g. surface roughness elements) of the terrain surrounding the meteorological tower, which effect was previously reported in Babić et al. (2015) as well. A comparison of the observed $\overline{u^{\prime} w^{\prime}}$ component normalized with respective variances and the ESDU 85020 (1985) data provided for $z_{0}=0.03 \mathrm{~m}$ with the tolerance range $\pm 20 \%$ is reported in Fig. 11 . The measured value is averaged during the entire time record, i.e. one value at each height for the entire time record. It can be noticed that the values agree well with the values recommended in the ESDU 85020 (1985) standard for open country with a few trees and hedges and isolated buildings.

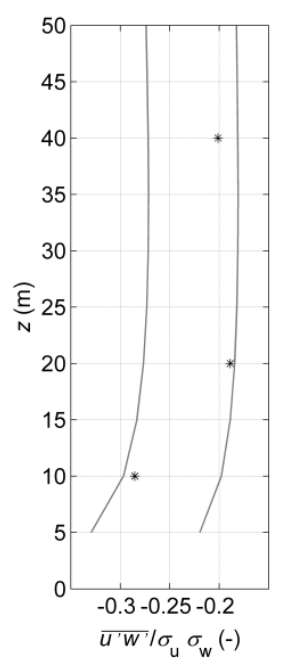

Fig. 11: Reynolds shear stress profile compared with the ESDU 85020 (1985) data provided for $z_{0}=0.03 \mathrm{~m}$ with tolerance range $\pm 20 \%$. Legend: star is average observed $\overline{u^{\prime} w^{\prime}} / \sigma_{u} \sigma_{v}$, grey solid line is ESDU 85020 (1985).

The turbulence length scales in $x$-direction related to $u^{\prime}, v^{\prime}$ and $w^{\prime}$ components are studied as well. First the applicability of Taylor's hypothesis of frozen turbulence to our data needs to be confirmed. Criterion of the applicability is that the ratio between the standard deviation of mean horizontal wind velocity and the mean horizontal wind velocity needs to be less than 0.5 (e.g. Stull, 1988). The analysis of the measured data comply with the requirements, and the validity of Taylor's hypothesis of frozen turbulence on all three height levels is confirmed. Therefore, Eq. (3) and (4) are used to 
410 calculate turbulence length scales. Summary statistics of the obtained values for the four time

411 averaging periods at $10 \mathrm{~m}, 20 \mathrm{~m}$ and $40 \mathrm{~m}$ height is provided in Tables $10-13$.

412 Table 10: Summary statistics for the ${ }^{x} L_{u},{ }^{x} L_{v}$ and ${ }^{x} L_{w}$ turbulence length scales for the time averaging period of 5 $413 \mathrm{~min}$.

414

\begin{tabular}{lcccccccccc}
\hline & \multicolumn{7}{c}{ Height } \\
\cline { 2 - 8 } Parameter & $10 \mathrm{~m}$ & $10 \mathrm{~m}$ & $10 \mathrm{~m}$ & $20 \mathrm{~m}$ & $20 \mathrm{~m}$ & $20 \mathrm{~m}$ & $40 \mathrm{~m}$ & $40 \mathrm{~m}$ & $40 \mathrm{~m}$ \\
\hline & ${ }^{x} L_{u}$ & ${ }^{x} L_{v}$ & ${ }^{x} L_{w}$ & ${ }^{x} L_{u}$ & ${ }^{x} L_{v}$ & ${ }^{x} L_{w}$ & ${ }^{x} L_{u}$ & ${ }^{x} L_{v}$ & ${ }^{x} L_{w}$ \\
\hline Median (m) & 97 & 61 & 29 & 124 & 97 & 51 & 165 & 143 & 78 \\
\hline Arithmetic mean (m) & 97 & 66 & 30 & 125 & 105 & 55 & 159 & 143 & 82 \\
\hline Min. value (m) & 28 & 21 & 8 & 28 & 20 & 16 & 32 & 34 & 21 \\
\hline Max. value (m) & 222 & 168 & 77 & 272 & 243 & 163 & 308 & 306 & 192 \\
\hline Standard deviation (m) & 34 & 24 & 10 & 45 & 43 & 21 & 56 & 53 & 27 \\
\hline
\end{tabular}

415

416

417

Table 11: Summary statistics for the ${ }^{\mathrm{x}} L_{u},{ }^{\mathrm{x}} L_{v}$ and ${ }^{\mathrm{x}} L_{w}$ turbulence length scales for the time averaging period of 8 $\min$.

\begin{tabular}{lccccccccc}
\hline & \multicolumn{7}{c}{ Height } \\
\cline { 2 - 8 } Parameter & $10 \mathrm{~m}$ & $10 \mathrm{~m}$ & $10 \mathrm{~m}$ & $20 \mathrm{~m}$ & $20 \mathrm{~m}$ & $20 \mathrm{~m}$ & $40 \mathrm{~m}$ & $40 \mathrm{~m}$ & $40 \mathrm{~m}$ \\
\hline & ${ }^{x} L_{u}$ & ${ }^{x} L_{v}$ & ${ }^{x} L_{w}$ & ${ }^{x} L_{u}$ & ${ }^{x} L_{v}$ & ${ }^{x} L_{w}$ & ${ }^{x} L_{u}$ & ${ }^{x} L_{v}$ & ${ }^{x} L_{w}$ \\
\hline Median (m) & 103 & 65 & 30 & 134 & 105 & 53 & 176 & 156 & 82 \\
\hline Arithmetic mean (m) & 103 & 70 & 31 & 132 & 112 & 58 & 166 & 152 & 85 \\
\hline Min. value (m) & 35 & 26 & 10 & 41 & 28 & 20 & 42 & 39 & 27 \\
\hline Max. value (m) & 215 & 164 & 73 & 264 & 245 & 154 & 302 & 306 & 190 \\
\hline Standard deviation (m) & 34 & 23 & 9 & 45 & 44 & 20 & 57 & 55 & 26 \\
\hline
\end{tabular}


421

422

423

424

425

426

427

428

429

430

431

432

433

434

435

436

437

438

439

440

441

442

443

444

445

446

447

448

449

450

451

452

Table 12: Summary statistics for the ${ }^{\mathrm{x}} L_{u},{ }^{\mathrm{x}} L_{v}$ and ${ }^{\mathrm{x}} L_{w}$ turbulence length scales for the time averaging period of 17 $\min$.

\begin{tabular}{lcccccccccc}
\hline & \multicolumn{7}{c}{ Height } \\
\cline { 2 - 8 } & $10 \mathrm{~m}$ & $10 \mathrm{~m}$ & $10 \mathrm{~m}$ & $20 \mathrm{~m}$ & $20 \mathrm{~m}$ & $20 \mathrm{~m}$ & $40 \mathrm{~m}$ & $40 \mathrm{~m}$ & $40 \mathrm{~m}$ \\
\hline & ${ }^{x} L_{u}$ & ${ }^{x} L_{v}$ & ${ }^{x} L_{w}$ & ${ }^{x} L_{u}$ & ${ }^{x} L_{v}$ & ${ }^{x} L_{w}$ & ${ }^{x} L_{u}$ & ${ }^{x} L_{v}$ & ${ }^{x} L_{w}$ \\
\hline Median (m) & 112 & 70 & 32 & 143 & 114 & 55 & 183 & 166 & 87 \\
\hline Arithmetic mean (m) & 109 & 75 & 32 & 141 & 120 & 60 & 174 & 161 & 88 \\
\hline Min. value (m) & 39 & 35 & 12 & 47 & 45 & 25 & 48 & 50 & 34 \\
\hline Max. value (m) & 192 & 146 & 61 & 246 & 240 & 141 & 295 & 280 & 175 \\
\hline Standard deviation (m) & 34 & 22 & 8 & 46 & 43 & 18 & 57 & 55 & 25 \\
\hline
\end{tabular}

Table 13: Summary statistics for the ${ }^{\mathrm{x}} L_{u},{ }^{\mathrm{x}} L_{v}$ and ${ }^{\mathrm{x}} L_{w}$ turbulence length scales for the time averaging period of 20 min.

\begin{tabular}{lcccccccccc}
\hline & \multicolumn{7}{c}{ Height } \\
\cline { 2 - 8 } Parameter & $10 \mathrm{~m}$ & $10 \mathrm{~m}$ & $10 \mathrm{~m}$ & $20 \mathrm{~m}$ & $20 \mathrm{~m}$ & $20 \mathrm{~m}$ & $40 \mathrm{~m}$ & $40 \mathrm{~m}$ & $40 \mathrm{~m}$ \\
\hline & ${ }^{x} L_{u}$ & ${ }^{x} L_{v}$ & ${ }^{x} L_{w}$ & ${ }^{x} L_{u}$ & ${ }^{x} L_{v}$ & ${ }^{x} L_{w}$ & ${ }^{x} L_{u}$ & ${ }^{x} L_{v}$ & ${ }^{x} L_{w}$ \\
\hline Median (m) & 113 & 71 & 32 & 145 & 115 & 56 & 184 & 169 & 88 \\
\hline Arithmetic mean (m) & 110 & 76 & 32 & 142 & 121 & 60 & 176 & 163 & 89 \\
\hline Min. value (m) & 43 & 36 & 13 & 50 & 48 & 26 & 51 & 52 & 37 \\
\hline Max. value (m) & 193 & 146 & 59 & 251 & 244 & 135 & 297 & 281 & 173 \\
\hline Standard deviation (m) & 34 & 22 & 8 & 46 & 43 & 18 & 57 & 55 & 24 \\
\hline
\end{tabular}

As for turbulence intensity and Reynolds shear stress, the median and arithmetic mean values of turbulence length scales remain nearly the same for different averaging times. The median values obtained for the ${ }^{x} L_{u}$ component range between $97 \mathrm{~m}$ and $113 \mathrm{~m}$ at $10 \mathrm{~m}$ height, between $124 \mathrm{~m}$ to 145 $\mathrm{m}$ at $20 \mathrm{~m}$ height and between $165 \mathrm{~m}$ and $184 \mathrm{~m}$ at $40 \mathrm{~m}$ height; the median values of ${ }^{x} L_{v}$ range between $61 \mathrm{~m}$ and $71 \mathrm{~m}$ at $10 \mathrm{~m}$ height, between $97 \mathrm{~m}$ and $115 \mathrm{~m}$ at 20 height and between $143 \mathrm{~m}$ and 
$169 \mathrm{~m}$ at $40 \mathrm{~m}$ height; the median values of ${ }^{x} L_{w}$ range between $29 \mathrm{~m}$ and $32 \mathrm{~m}$ at the lowest height 454 level, between $51 \mathrm{~m}$ and $56 \mathrm{~m}$ at the middle height level and between $78 \mathrm{~m}$ and $88 \mathrm{~m}$ at the highest

455

456

457

458

459

460

461

462 height level. Standard deviation for the turbulence length scales, which is approximately $30 \%$ of the respective measured value, suggests moderate dispersion of the obtained data.

To investigate the dependence of turbulence length scales on the average wind velocity, the time series of turbulence length scales are presented in Figs. 12 - 14 for the averaging period of $17 \mathrm{~min}$. The trends in the respective time series for other averaging periods are the same.

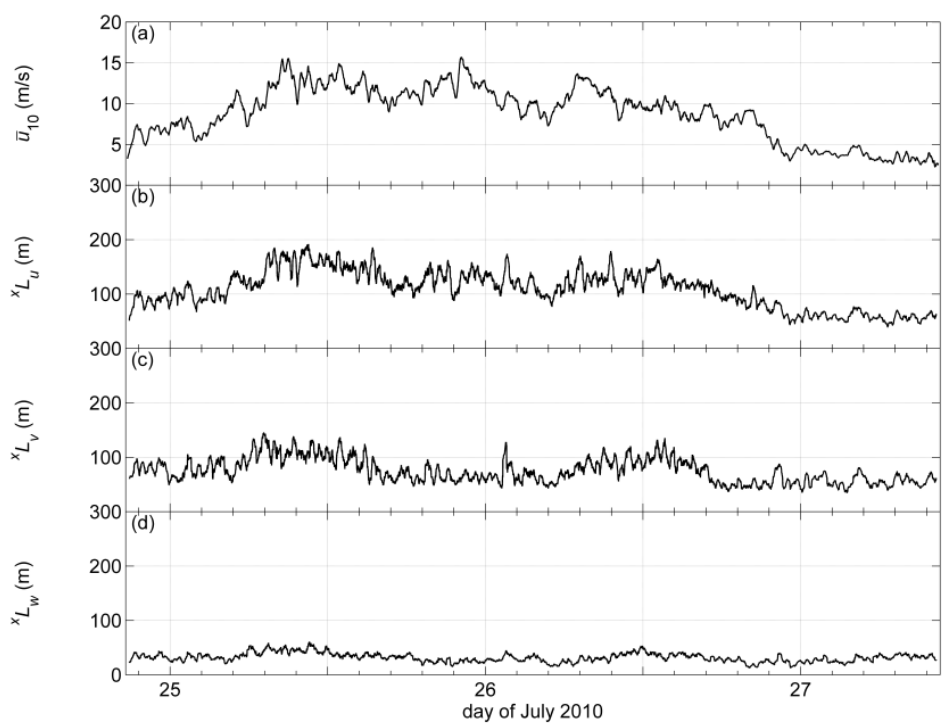

Fig. 12: (a) Mean wind velocity in the main $(x)$ wind direction averaged over the time scale of $17 \mathrm{~min}$ at $10 \mathrm{~m}$ height and time series of the (b) ${ }^{\mathrm{x}} L_{u},(\mathrm{c})^{\mathrm{x}} L_{v}$ and $(\mathrm{d})^{\mathrm{x}} L_{w}$ turbulence length scales for averaging time $17 \mathrm{~min}$. 


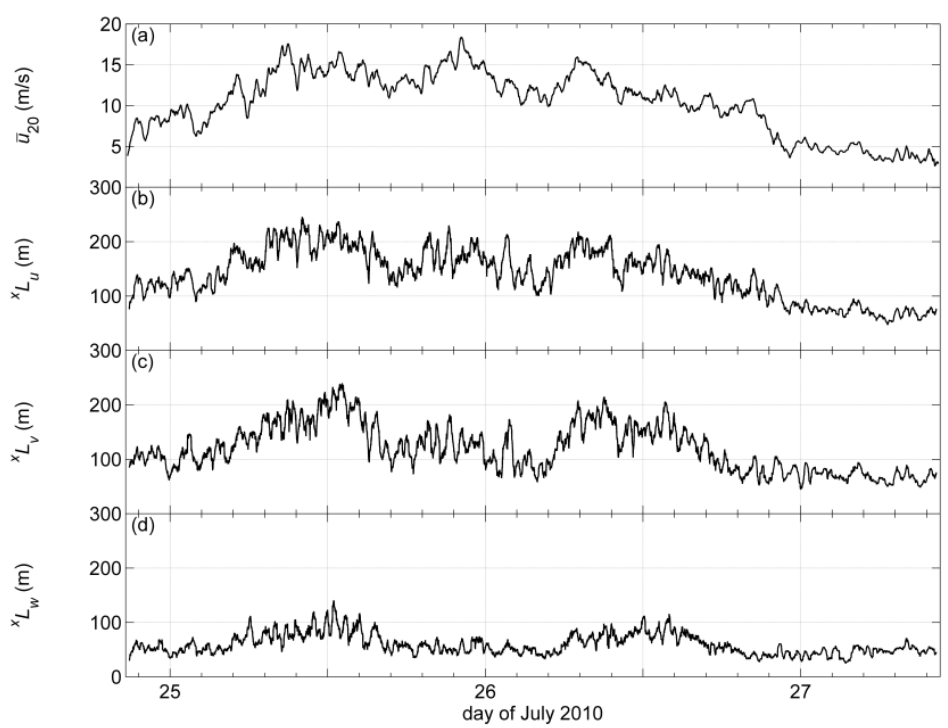

Fig. 13: (a) Mean wind velocity in the main $(x)$ wind direction averaged over the time scale of $17 \mathrm{~min}$ at $20 \mathrm{~m}$ height and time series of the (b) ${ }^{\mathrm{x}} L_{u},(\mathrm{c})^{\mathrm{x}} L_{v}$ and $(\mathrm{d})^{\mathrm{x}} L_{w}$ turbulence length scales for averaging time $17 \mathrm{~min}$.

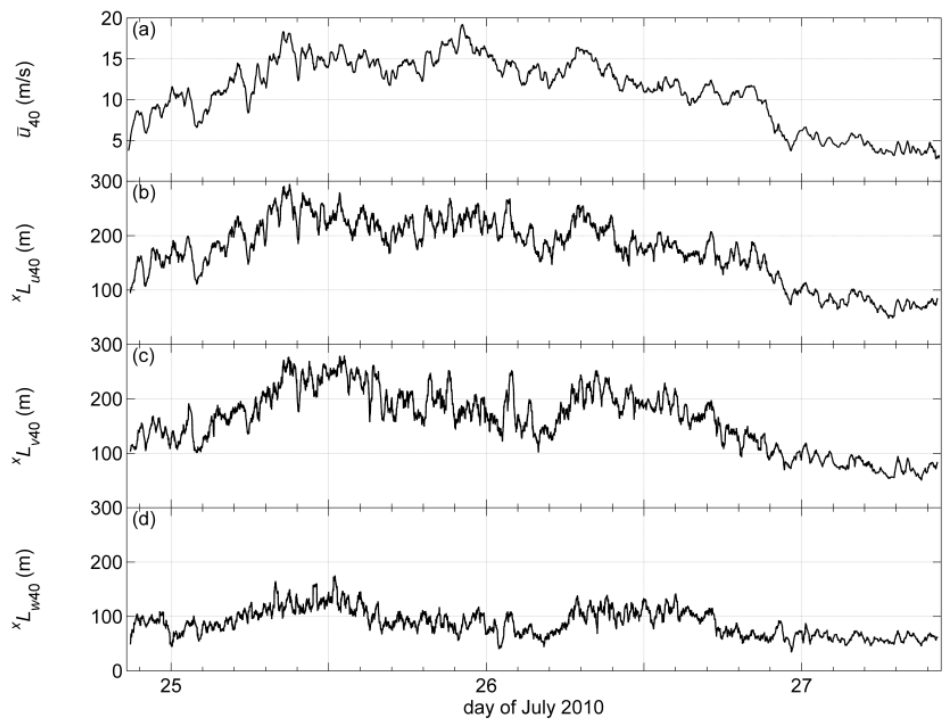

Fig. 14: (a) Mean wind velocity in the main $(x)$ wind direction averaged over the time scale of $17 \mathrm{~min}$ at $40 \mathrm{~m}$ height and time series of the (b) ${ }^{\mathrm{x}} L_{u},(\mathrm{c})^{\mathrm{x}} L_{v}$ and $(\mathrm{d})^{\mathrm{x}} L_{w}$ turbulence length scales for averaging time $17 \mathrm{~min}$.

The time series of ${ }^{x} L_{u},{ }^{x} L_{v}$ and ${ }^{x} L_{w}$ in Figs. 12 - 14 confirm the data obtained by statistical analysis,

471 while an increase in the ${ }^{x} L_{u},{ }^{x} L_{v}$ and ${ }^{x} L_{w}$ values with increasing mean wind velocity and vice versa can be noticed. There are no day to night trends. 
Moreover, to investigate vertical variations of turbulence length scales, vertical profile of the observed parameters for the time averaging period of $17 \mathrm{~min}$ is presented in Fig 15. The vertical profiles for the other three time averaging periods are not reported because the trends are basically the same.

(a)

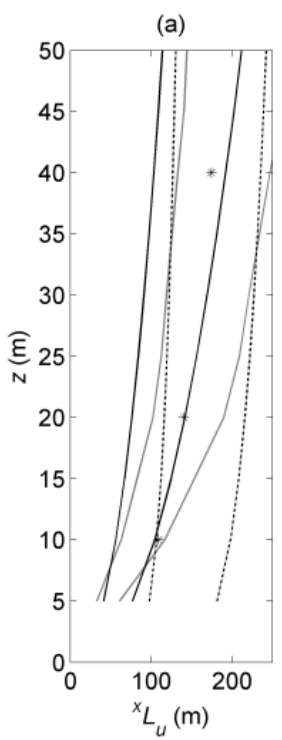

(b)

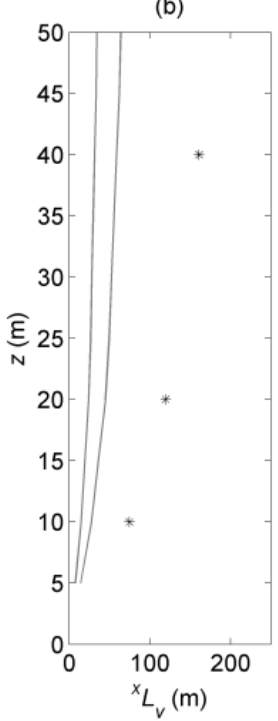

(c)

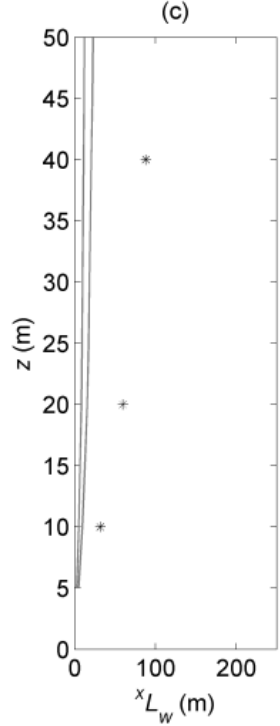

Fig 15: Vertical profiles of turbulence length scales (a) ${ }^{x} L_{u}$, (b) ${ }^{x} L_{v}$ and (c) ${ }^{x} L_{w}$ component for the averaging time

17 min calculated through the entire time record compared with the values in international standards with tolerance range of $\pm 30 \%$. Legend: star is observed turbulence length scale, grey solid line is ESDU 85020 (1985) with $z_{0}=0.03 \mathrm{~m}$, black solid line is EN 1991 Eurocode 1 (2005), black dotted line is ASCE 7-05 (2006).

The values reported as stars in Fig. 15 represent the average values calculated through the entire time record, meaning one value in each height for the entire recording period. It can be observed that for this particular Bora episode, turbulence length scales increase with height, which is in agreement with atmospheric physics (e.g. Stull, 1988) and previous studies (e.g. Večenaj et al. 2010, 2011). In comparison with the international standards, it can be noticed that ${ }^{x} L_{u}$ is in good agreement with the international standards ASCE 7-05 (2006), EN 1991 Eurocode 1 (2005) and ESDU 85020 (1985). The other two measured components, ${ }^{x} L_{v}$ and ${ }^{x} L_{w}$, are considerably larger compared to the values predicted in ESDU 85020 (1985) for $\mathrm{z}_{0}=0.03 \mathrm{~m}$. This is likely due to plausible terrain-induced boundary-layer flow separation, recirculation and reattachment phenomena that is to be further investigated in more detail in the future. 


\section{Conclusions}

493

494

495

496

497

498

499

500

501

502

503

504

505

506

507

508

509

510

511

512

513

514

515

516

Field measurements are carried out on the meteorological tower close to the city of Split, Croatia to further elucidate the Bora wind turbulence near the ground. These unique three-level high-frequency measurements focus on the analysis of turbulence intensity, Reynolds shear stress and turbulence length scales for one summertime Bora wind episode in comparison with the values in major international wind engineering standards. This is for the first time that the Bora Reynolds stress is assessed directly from a suitable data set ever. Turbulence intensity and Reynolds shear stress are not very sensitive to changes in the mean wind velocity, as the observed values remain within the same range during the time record. This behavior applies on mean wind velocities larger than $5 \mathrm{~m} / \mathrm{s}$, while for smaller velocities the spread of values increases considerably. Turbulence length scales increase with increasing mean wind velocity and vice versa. With increasing height from the ground, turbulence intensity and absolute Reynolds shear stress decrease, while turbulence length scales increase. This is in agreement with characteristics of the standard ABL. However, while turbulence intensity, Reynolds shear stress and longitudinal turbulence length scales generally agree well with the values recommended in international standards for the respective terrain type, turbulence length scales related to the lateral and vertical velocity fluctuations are much larger than the standard values. The trends observed are not influenced by the choice of the time averaging period; there are no day to night trends, while the median and arithmetic mean values are nearly the same. In order to understand the real importance of the Bora wind characterization from the engineering point of view, further work is still required with respect to Bora turbulence for other terrain types, seasons and elevations from the ground, as well as the extreme value distributions in comparison with cyclonic events.

\section{ACKNOWLEDGMENTS}

PL acknowledges the Meteorological and Hydrological Service for support, ŽV, HK and BG are supported by CATURBO, No. 09/151, financed by the National Science Foundation. The support is provided in part by the Grant Agency of the Czech Republic under the project GAČR 14-12892S, as 
well as the UKF grant 16/08 (WINDEX), while Kristian Horvath is thanked for overall support and patience.

\section{References}

Àgústsson, H., Ólafsson, H., 2007.Simulating a severe windstorm in complex terrain. Meteorologische Zeitschrift 16, 111-122.

AIJ, 2006. AIJ Recommendations for Loads on Buildings (in English). Architectural Institute of Japan, Tokyo, Japan.

American Society of Civil Engineers (ASCE), 2006. Minimum design loads for buildings and other structuresASCE/SEI 7-05. Reston, Virginia, USA.

Babić, N., Večenaj, Ž., Kozmar, H., Horvath, K., De Wekker, S.F.J., Grisogono, B., 2015. On turbulent fluxes during strong winter bora wind events. Boundary-Layer Meteorology, in press

Bajić, A., 1988.The strongest Bora event during ALPEX SOP. Rasprave-Papers 23, 1-9.

Bajić, A., 1989. Severe Bora on the northern Adriatic. Part I: Statistical analysis. Rasprave-Papers 24, $1-9$.

Belušić, D., Klaić, Z.B., 2004. Estimation of Bora wind gusts using a limited area model. Tellus 56A, 296-307.

Belušić, D., Pasarić, M., Orlić, M., 2004. Quasi-periodic bora gusts related to the structure of the troposphere. Quarterly Journal of the Royal Meteorological Society 130, 1103-1121.

Belušić, D., Pasarić, M., Pasarić, Z., Orlić, M., Grisogono, B., 2006. A note on local and non-local properties of turbulence in the bora flow. Meteorologische Zeitschrift 15, 301-306.

Belušić, D.,Klaić, Z.B., 2006. Mesoscale dynamics, structure and predictability of a severe Adriatic Bora case. Meteorologische Zeitschrift 15, 157-168.

Belušić, D., Žagar, M., Grisogono, B., 2007. Numerical simulation of pulsations in the Borawind, Quarterly Journal of the Royal Meteorological Society 133, 1371-1388.

Belušić, D., Hrastinski, M., Večenaj, Ž., Grisogono, B., 2013. Wind regimes associated with a mountain gap at the northeastern Adriatic coast. Journal of Applied Meteorology and Climatology $52,2089-2105$. 
Counihan, J., 1975. Adiabatic atmospheric boundary layers: a review and analysis of data from the period 1880-1972. Atmospheric Environment, 9, 871-905.

Enger, L.,Grisogono, B., 1998. The response of bora-type flow to sea surface temperature. Quarterly Journal of the Royal Meteorological Society 124, 1227-1244.

ESDU Data Item No. 74030, 1976.Characteristics of atmospheric turbulence near the ground. Part I: definitions and general information. Engineering Science Data Unit, London, UK.

ESDU Data Item No. 85020, 1985. Characteristics of atmospheric turbulence near the ground. Part II: single point data for strong winds (neutral atmosphere). Engineering Science Data Unit, London, UK.

EN 1991 Eurocode 1, 2005. Actions on structures - General actions - Part 1-4: Wind actions.

Grisogono, B., Belušić, D., 2009. A review of recent advances in understanding the meso- and microscale properties of the severe Bora wind. Tellus 61A, 1-16.

Grisogono, B., T. Jurlina, Ž. Večenaj and I. Güttler, 2015: Weakly non-linear Prandtl model for simple slope flows. Quarterly Journal of the Royal Meteorological Society, 2406141, 883-892. http://onlinelibrary.wiley.com/doi/10.1002/qj.2406/abstract.

Grubišić, V., 2004. Bora-driven potential vorticity banners over the Adriatic. Quarterly Journal of the Royal Meteorological Society 130, 2571-2603.

Heimann, D., 2001. A model-based wind climatology of the eastern Adriatic coast. Meteorologische Zeitschrift 10, 5-16.

Holmes, J.D., 2007. Wind loading of structures. Taylor \& Francis, London, UK.

Horvath, K., Ivatek Šahdan, S., Ivančan Picek, B., Grubišić, V., 2009. Evolution and structure of severe cyclonic Bora: contrast between the northern and southern Adriatic. Weather Forecasting 24, 946-964.

Horvath, K., Večenaj, Ž., Grisogono, B., 2012. Bora flow over the complex orography of the midAdriatic region. 15th Conference on Mountain Meteorology, Steamboat Springs, Colorado, USA.

ISO 4354, 1997. Wind actions on structures. International standard organization. 
Jackson, P.L., Mayr, G., Vosper, S., 2013. Dynamically-Driven Winds, in: Chow F.K., De Wekker S.F.J., Snyder B.J. (Eds.), Mountain Weather Research and Forecasting: Recent Progress and Current Challenges. Springer, Dordrecht, Netherlands.

Jeromel, M., Malačič, V., Rakovec, J., 2009. Weibull distribution of Bora and sirocco winds in the northern Adriatic Sea. Geofizika 26, 85-100.

Jurčec, V., 1981. On mesoscale characteristics of Bora conditions in Yugoslavia. Pure and Applied Geophysics 119, 640-657.

Jurčec, V., Visković, S., 1994. Mesoscale characteristics of southern Adriatic Borastorms. Geofizika $11,33-46$.

Klemp, J. B., Durran, D. R., 1987. Numerical modeling of Bora winds. Meteorology and Atmospheric Physics 36, 215-227.

Kozmar, H., Butler, K., Kareem, A., 2012a. Transient cross-wind aerodynamic loads on a generic vehicle due to bora gusts. Journal of Wind Engineering and Industrial Aerodynamics 111, 73-84.

Kozmar, H., Procino, L., Borsani, A., Bartoli, G., 2012b. Sheltering efficiency of wind barriers on bridges. Journal of Wind Engineering and Industrial Aerodynamics 107-108, 274-284.

Kozmar, H., Procino, L., Borsani, A., Bartoli, G., 2014. Optimizing height and porosity of roadway wind barriers for viaducts and bridges. Engineering Structures 81, 49-61.

Kozmar, H., Butler, K., Kareem A., 2015. Downslope gusty wind loading of vehicles on bridges. Journal of Bridge Engineering, DOI: 10.1061/(ASCE)BE.1943-5592.0000748

Lepri, P., Kozmar, H., Večenaj, Ž., Grisogono, B., 2014. A summertime near-ground velocity profile of the Bora wind. Wind and Structures 19 (5), 505-522.

Magjarević, V., Večenaj, Ž., Horvath, K. and Grisogono, B., 2011. Turbulence averaging interval for summer Bora flows at the middle of the NE Adriatic coast. 31st International Conference on Alpine Meteorology, Aviemore, Scotland.

Makjanić, B., 1978. Bura, jugo, etezija. Prilozi poznavanju vremena i klime SFRJ 5, 1-43. (In Croatian). 
Neiman, P.J., Hardesty, R.M., Shapiro, M.A., Cupp, R.E., 1988. Doppler lidar observations of a downslope windstorm. Monthly Weather Review 116, 2265-2275.

Oncley, S.P., Friehe, C.A., Businger, J.A., Itsweire, E.C., LaRue, J.C., Chang, S.S., 1996. Surface layer fluxes, profiles and turbulence measurements over uniform terrain under near-neutral conditions. Journal of the Atmospheric Sciences 53, 1029-1044.

Petkovšek, Z., 1976. Periodicity of Bora gusts. Rasprave-Papers 20, 67-75.

Petkovšek, Z., 1982. Gravity waves and Bora gusts. Annalen für Meteorologie 19, 108-110.

Petkovšek, Z., 1987. Main Bora gusts - a model explanation. Geofizika 4, 41-50.

Poje, D., 1992. Wind persistence in Croatia. International Journal of Climatology 12, 569-586.

Rakovec, J., 1987.Preliminary report on spectral characteristics of Bora on the island of Rab. Geofizika 4, 35-40.

Simiu, E., Scanlan, R. H., 1996. Wind effects on structures. John Wiley, New York, NY, USA.

Smith, R.B., 1987. Aerial observations of Yugoslavian Bora. Journal of the Atmospheric Sciences 44, 269-297.

Solari, G., Burlando, M., De Gaetano, P., Repetto, M.P., 2015. Characteristics of thunderstorms relevant to the wind loading of structures. Wind and Structures 20(6), 763-791.

Stull, R.B., 1988.Anintroduction to boundary layer meteorology. Kluwer, Dordrecht, Netherlands.

Tutiš, V., 1988, Bora on the Adriatic coast during ALPEX SOP on 27-30 April 1982. Rasprave-Papers $23,45-56$.

Večenaj,Ž., Belušić, D., Grisogono, B., 2010. Characteristics of the near-surface turbulence during a bora event. Annales Geophysicae 28, 155-163.

Večnaj, •., De Wekker, S.F.J., Grubišić, V., 2011. Near surface characteristics of the turbulence structure during a mountain wave event. Journal of Applied Meteorology and Climatology 50, 1088-1106.

Večenaj, Ž., 2012, Characteristics of the Bora related turbulence, Ph.D. Dissertation, University of Zagreb, Zagreb, Croatia. 
622 Večenaj, Ž., Belušić, D., Grubišić, V., Grisogono, B., 2012. Along-coast features of bora related 623 turbulence. Boundary Layer Meteorology 143, 527-545.

624 Vučetić, V., 1991. Statistical analysis of severe Adriatic Bora. Croatian Meteorological Journal 26, 41 $625 \quad 51$.

626 Wilks, D.S., 1995. Statistical Methods In The Atmospheric Sciences. Academic Press, New York, NY, 627 USA.

628 Yoshino, M.M., 1976. Local Wind Bora. University of Tokyo Press, Tokyo, Japan. 